\title{
Performance Evaluation of single slope solar still by the inclusion of Palm Flower powder and micro Phase Change Material (mPCM) for the enhancement of productivity
}

\section{Arivazhagan Sampathkumar}

NIT Puducherry: National Institute of Technology Puducherry

SENDHIL KUMAR NATARAJAN ( $\sim$ drsendhil1980iitmuk@gmail.com )

National Institute of Technology Puducherry https://orcid.org/0000-0003-3257-4570

\section{Research Article}

Keywords: palm flower powder, micro Phase Change Material, thermal conductivity, enviro-economic analysis, solar still

Posted Date: March 2nd, 2022

DOI: https://doi.org/10.21203/rs.3.rs-1299420/v1

License: (c) (1) This work is licensed under a Creative Commons Attribution 4.0 International License. Read Full License 

micro Phase Change Material (mPCM) for the enhancement of productivity

3

4

5

6

7

8

\section{Arivazhagan Sampathkumar, Sendhil Kumar Natarajan*}

Solar Energy Laboratory, Department of Mechanical Engineering,

National Institute of Technology Puducherry, Karaikal, UT of Puducherry, India.

*Corresponding Author: Assistant Professor and Head,

Email: drsendhil1980iitmuk@gmail.com; Tel: +91-9597541522 


\section{Abstract:}

The objective of the work is to investigate the single slope solar still for the enhancement in productivity by the inclusion of optimum weight of palm flower powder of micro-sized in the absorber basin and optimum weight\% of micro-Phase Change Material (mPCM) under the absorber basin. In this regard, the effect of different weights of palm flower powder such as 10,30, 45, 50, 55, 70, 100, 120 and $150 \mathrm{~g}$ in the absorber was analysed. The solar still with $50 \mathrm{~g}$ of palm flower powder in the absorber increased the productivity by $37.25 \%$ whereas, for 10,30 , $45,55,70,100,120$ and $150 \mathrm{~g}$ were $11.85,24.78,36.1,36.8,34.35,33.05,10.25$ and $-20.22 \%$ respectively. The effect of different weight $\%$ of micro-sized palm flower powder such as 5, 10, 15 and 20 wt $\%$, in paraffin wax, was investigated. The paraffin wax with $20 \mathrm{wt} \%$ of micro-sized palm flower powder has a better thermal conductivity of $0.33 \mathrm{~W} / \mathrm{mK}$. The experimentation was carried out with $50 \mathrm{~g}$ of micro-sized palm flower powder in the absorber basin and $20 \mathrm{wt} \% \mathrm{mPCM}$ under the absorber basin solar still (PCMPFP-SS) and Conventional Solar Still (CSS). The overall yield of PCMPFP-SS was $4670 \mathrm{ml} / \mathrm{m}^{2}$-day on day 1 and $4250 \mathrm{ml} / \mathrm{m}^{2}$-day on day 2, for CSS it was $3030 \mathrm{ml} / \mathrm{m}^{2}$-day on day 1 and $2800 \mathrm{ml} / \mathrm{m}^{2}$-day on day 2 . It was evaluated that the Cost per Litre of PCMPFP-SS was \$ 0.025 and \$ 0.032 for CSS.

\section{Highlights:}

- The optimum weight of micro-sized palm powder was $50 \mathrm{~g}$ for higher productivity.

- $\quad$ The optimum weight $\%$ of micro-sized palm powder in the PCM was $20 \mathrm{wt} \%$.

- The value of thermal conductivity for mPCM was $57.14 \%$ higher than PCM without microparticles.

- $\quad$ The increase in productivity of PCMPFP-SS was $54.12 \%$ on day 1 and $51.78 \%$ on day 2.

- $\quad$ The Cost per litre of PCMPFP-SS was decreased by $33.33 \%$.

Keywords: palm flower powder; micro Phase Change Material, thermal conductivity, enviro-economic analysis, solar still 
Nomenclature:

\begin{tabular}{|c|c|}
\hline $\mathrm{U}$ & Uncertainty \\
\hline A & Accuracy \\
\hline $\mathrm{d}_{\mathrm{f}}$ & Final distillate value \\
\hline $\mathrm{d}_{\mathrm{i}}$ & Initial distillate value \\
\hline $\mathrm{u}_{d_{w}}$ & uncertainty in productivity \\
\hline$\alpha_{w}$ & Absorptivity of water \\
\hline$\tau_{w}$ & Water transmissivity \\
\hline$\alpha_{b}$ & absorber basin absorptivity \\
\hline$\tau_{g}$ & Transmissivity of glass \\
\hline$\alpha_{g}$ & Absorptivity of glass \\
\hline$m_{w}$ & Mass of water $(\mathrm{kg})$ \\
\hline$m_{b}$ & absorber basin mass $(\mathrm{kg})$ \\
\hline$m_{g}$ & glass mass $(\mathrm{kg})$ \\
\hline$C_{p w}$ & Specific heat capacity of water $(\mathrm{KJ} / \mathrm{Kg}-\mathrm{K})$ \\
\hline$C_{p b}$ & Specific heat capacity of absorber basin $(\mathrm{KJ} / \mathrm{Kg}-\mathrm{K})$ \\
\hline$C_{p g}$ & Specific heat capacity - glass $(\mathrm{KJ} / \mathrm{Kg}-\mathrm{K})$ \\
\hline$C_{p v}$ & Specific heat capacity - vapour mixture $(\mathrm{KJ} / \mathrm{Kg}-\mathrm{K})$ \\
\hline$K_{v}$ & Thermal conductivity of vapour mixture $(\mathrm{W} / \mathrm{m}-\mathrm{K})$ \\
\hline$d$ & space between the absorber water and inner glass $(\mathrm{m})$ \\
\hline$g$ & Gravity $\left(\mathrm{m} / \mathrm{s}^{2}\right)$ \\
\hline$\beta$ & Volume expansion coefficient $(1 / \mathrm{K})$ \\
\hline$d t$ & the difference in temperature between the absorber water and inner glass \\
\hline$\rho$ & Density $\left(\mathrm{kg} / \mathrm{m}^{3}\right)$ \\
\hline$\mu$ & Dynamic viscosity $\left(\mathrm{N}-\mathrm{s} / \mathrm{m}^{2}\right)$ \\
\hline$A_{w}$ & Area of water $\left(\mathrm{m}^{2}\right)$ \\
\hline$A_{b}$ & Area of absorber basin $\left(\mathrm{m}^{2}\right)$ \\
\hline$A_{g}$ & Area of glass $\left(\mathrm{m}^{2}\right)$ \\
\hline
\end{tabular}




\begin{tabular}{|c|c|}
\hline$h_{c}$ & coefficient of convective heat transfer - water $\left(\mathrm{W} / \mathrm{m}^{2} \mathrm{~K}\right)$ \\
\hline$h_{t, i}$ & Total inner - coefficient of convective heat transfer $\left(\mathrm{W} / \mathrm{m}^{2} \mathrm{~K}\right)$ \\
\hline$h_{r, i}$ & Inner - coefficient radiative heat transfer $\left(\mathrm{W} / \mathrm{m}^{2} \mathrm{~K}\right)$ \\
\hline$h_{e, i}$ & inner - coefficient of evaporative heat transfer $\left(\mathrm{W} / \mathrm{m}^{2} \mathrm{~K}\right)$ \\
\hline$h_{t, o}$ & Total outer - coefficient of convective heat transfer $\left(\mathrm{W} / \mathrm{m}^{2} \mathrm{~K}\right)$ \\
\hline$h_{c, i}$ & Inner - coefficient of convective heat transfer $\left(\mathrm{W} / \mathrm{m}^{2} \mathrm{~K}\right)$ \\
\hline$h_{c, o}$ & Outer - coefficient of convective heat transfer $\left(\mathrm{W} / \mathrm{m}^{2} \mathrm{~K}\right)$ \\
\hline$h_{r, o}$ & Outer - coefficient of radiative heat transfer $\left(\mathrm{W} / \mathrm{m}^{2} \mathrm{~K}\right)$ \\
\hline$U_{b}$ & Overall - basin heat transfer coefficient $\left(\mathrm{W} / \mathrm{m}^{2} \mathrm{~K}\right)$ \\
\hline$T_{w}$ & Water temperature $\left({ }^{\circ} \mathrm{C}\right)$ \\
\hline$T_{g}$ & Glass temperature $\left({ }^{\circ} \mathrm{C}\right)$ \\
\hline$T_{b}$ & Absorber basin temperature $\left({ }^{\circ} \mathrm{C}\right)$ \\
\hline$T_{a}$ & atmospheric temperature $\left({ }^{\circ} \mathrm{C}\right)$ \\
\hline$T_{S}$ & Sky temperature $\left({ }^{\circ} \mathrm{C}\right)$ \\
\hline$P_{w}$ & Partial pressure of water $\left(\mathrm{N} / \mathrm{m}^{2}\right)$ \\
\hline$P P_{g}$ & Partial pressure of glass $\left(\mathrm{N} / \mathrm{m}^{2}\right)$ \\
\hline$\varepsilon_{\text {eff }}$ & Effective emissivity \\
\hline$\varepsilon_{g}$ & Emissivity of glass \\
\hline$\varepsilon_{w}$ & Emissivity of glass \\
\hline$\sigma$ & Stefan-Boltzmann constant $\left(5.67 \times 10^{-8} \mathrm{~W} / \mathrm{m}^{2} \mathrm{~K}^{-4}\right)$ \\
\hline$Q_{e, i}$ & Inner Heat transfer $(\mathrm{W})$ \\
\hline$L_{h}$ & Latent heat of vaporization of water $(\mathrm{KJ} / \mathrm{Kg})$ \\
\hline$P_{h}$ & Hourly productivity (kg) \\
\hline$P_{d}$ & Daily productivity $(\mathrm{kg})$ \\
\hline$\eta_{\text {ins }}$ & Instantaneous thermal efficiency \\
\hline$\eta_{\text {passive }}$ & Cumulative still efficiency \\
\hline$I$ & Incident global solar radiation $\left(\mathrm{W} / \mathrm{m}^{2}\right)$ \\
\hline$A$ & Area of the absorber basin $\left(\mathrm{m}^{2}\right)$ \\
\hline
\end{tabular}




\begin{tabular}{|c|c|}
\hline $\mathrm{Nu}$ & Nusselt number \\
\hline$G r$ & Grashoff number \\
\hline $\mathrm{Pr}$ & Prandtl number \\
\hline CSS & Conventional Solar Still \\
\hline PCMAAF-SS & agar fibre and mPCM in the solar still \\
\hline $\mathrm{mL} / \mathrm{m}^{2}$ & Millilitre per day \\
\hline $\mathrm{cm}$ & Centimetre \\
\hline $\mathrm{m}$ & Metre \\
\hline $\mathrm{mm}$ & Millimetre \\
\hline $\mathrm{m}^{2}$ & Square metre \\
\hline $\mathrm{W} / \mathrm{m}^{2}$ & Watt per square metre \\
\hline $\mathrm{W}$ & Watt \\
\hline${ }^{\circ} \mathrm{C}$ & Degree Celsius \\
\hline $\mathrm{mL}$ & Millilitre \\
\hline $\mathrm{KJ} / \mathrm{Kg}-\mathrm{K}$ & kilojoule per kilogram Kelvin \\
\hline $\mathrm{W} / \mathrm{m}-\mathrm{K}$ & Watt per metre Kelvin \\
\hline
\end{tabular}

\section{Introduction:}

42 The most vital and primary nutrient for the survival of all living species on the earth is water. The earth's surface is covered by 71 percent water, with freshwater accounting for only around 3\% of the total. The remaining $97 \%$ of water is held by the ocean. The freshwater resources are rapidly depleting as a result of rapid population expansion and industry exploitations. The depletion of freshwater resources leads to water scarcity and droughts. The ocean water contains a high percentage of salt which cannot be consumed directly. The conversion of seawater to safe drinking water has been the most effective way to overcome water scarcity. The desalination process converts salt water into potable water. The desalination process is driven by conventional sources of energy. Another serious concern that must be addressed is the carbon impact due to conventional energy (Mathioulakis et al. 2007; Qiblawey and Banat 2008; Sharon and Reddy 2015; Patel et al. 2019; Ahmed et al. 2021). The best possible solution is a renewable energy-driven desalination technology which can be accomplished with the help of solar stills. The stills can be easily made by utilising locally accessible materials in any region. The construction is simple, easy to handle and also cost-effective. The main downside of solar still is its lesser yield. Scientists 
across the world are using different approaches to increase productivity (Thirugnanasambandam et al. 2010; Jani and Modi 2018; Bhargva and Yadav 2021; Ho et al. 2021; Singh et al. 2021). The various approaches for the enhancement of solar still productivity have been discussed elaborately in the literature review section.

\section{Literature Review:}

\section{Productivity Enhancement of Solar still based on geometry and extended surfaces}

The absorption of more global radiation in the still can be achieved by more surface area in the design (Kabeel et al. 2019)(Shinde et al. 2020). Sharshir et al. (Sharshir et al. 2020a) experimentally analysed the pyramid still with wick material and nanofluid, it was found that the pyramid solar still with wick material and copper oxide nanofluid has the higher productivity of about $72.95 \%$ whereas for inclusion of wick in the pyramid still has 45 $\%$ increase in productivity relative to the conventional pyramid still. Dubey et al. (Dubey et al. 2021) analysed the environment, energy, exergy and economic for the double slope solar still connected with evacuated tubes. It was found that the high productivity of freshwater with emission reduction and less cost can be assessed using the integrated system. Hassan et al. (Hassan et al. 2019) investigated the influence of saline water in the solar still which was combined with a parabolic trough collector system. The study reveals that the sand and wire mesh medium increased the productivity by $13.7 \%$ and $3.1 \%$ compared to pure saline water. Mostafavi et al. (Mostafavi et al. 2020) developed a semi-analytical model for longitudinal and transverse fins into the Phase Change Materials for the solar thermal application system by using the perturbation method. The results showed that the extended surfaces in the solar thermal system increased productivity. Moungar et al. (Moungar et al. 2017) investigated the effects of fins which was immersed in the solar still. It was revealed that distance between fins has no significant improvement whereas the height of fins played a major role in productivity. The productivity was increased when the fin heights increased from $2-5 \mathrm{~cm}$ whereas the productivity was decreased when height changed from 6 to $8 \mathrm{~cm}$. Suraparaju and Natarajan (Suraparaju and Natarajan 2021a) experimentally investigated the absorber basin with novel bottom fined absorber basin to improve the transfer of heat from absorber to the phase change materials under the basin. The experiment was carried out with three setups, one with a hollow finned absorber, and another with a solid fin absorber basin and conventional solar still. The experiment revealed that still with hollow finned absorber basin has higher productivity of $4085 \mathrm{~mL} / \mathrm{m}^{2} / \mathrm{day}$. The yield of solar still with solid fin absorber and conventional solar still was $3485 \mathrm{~mL} / \mathrm{m}^{2} /$ day and $2885 \mathrm{~mL} / \mathrm{m}^{2} / \mathrm{day}$. The hollow fin absorber basin has more solar still has more productivity because of the availability of space inside the hollow fins which helps to conduct more heat from the absorber to the latent heat storage system. Kabeel et al. (Kabeel et al. 2020) investigated the pyramid still with hollow fins and solid fins implanted into the 
latent thermal storage material, the result showed that hollow fins pyramid solar still has increased in yield of $5.75 \mathrm{~L} / \mathrm{m}^{2} /$ day whereas for solid fins it was $4.02 \mathrm{~L} / \mathrm{m}^{2} /$ day. Modi and Jani (Modi and Jani 2021) assessed the double slope solar still without and with hollow fins analytically and experimentally. The theoretical and experimental results were compared and found that absorption of solar radiation was increased by $23.78 \%$ with the inclusion of hollow fins, the productivity was increased by $51.74 \%$.

\section{Productivity Enhancement by incorporation of Wick Materials}

The wick material act as the porous medium in the absorber basin. The wick material increases more wet surface area, resulting in more evaporation (Fale et al. 2021) (Shubhajyothi et al. 2020). Sharshir et al. (Sharshir et al. 2020c) investigated the still with a novel wick-metal chip pad. The results showed that the copper metal chips in the pad enhanced the productivity by $54.2 \%$ whereas in the aluminium chips filled pad the increase in productivity was $34.23 \%$. Modi and Modi (Modi and Modi 2020) experimentally analysed the wick pile of jute cloth in the single slope solar still with a double basin. The results revealed that the inclusion of wick material increased the productivity by $21.12 \%, 23.71 \%$ on the experiment days. Sharshir et al. (Sharshir et al. 2020b) studied the still with nanoparticles and linen wicks. The still with linen wick materials and nanoparticles of black colour increased the productivity by $80.57 \%$ and energy efficiency was increased by $110.5 \%$. Saravanan and Murugan (Saravanan and Murugan 2020) investigated the inclusion of various wick materials such as terry cotton, jute cloth, polyester and woollen fabrics in the square pyramid solar still. The results stated that the inclusion of woollen fabrics has better productivity which was $40.3 \%$ more than conventional solar still, 33.1 $\%, 20.9 \%$ and $9.4 \%$ higher than that of polyester cloth, terry cotton and jute cloth respectively. Baskaran et al. (Baskaran et al. 2021) investigated the solar still with cotton gauze as wick material and it was found that the productivity was increased by $46.49 \%$. Younes et al. (Younes et al. 2021) experimentally investigated the solar still with corrugated wick and half barrel wick solar still. The results revealed that the increase in productivity for solar still with half barrel wick and the corrugated wick was $52 \%$ and $43 \%$ when compared with CSS.

\section{Enhancement in productivity by Coating/Inclusion of Micro/Nano Particles in solar still}

The temperature of the water can be increased by the inclusion of micro/nanoparticles in the absorber basin. The micro/nanoparticles absorb more heat from global solar radiation. The rise in water temperature leads to more evaporation resulting in enhancement of productivity. The graphite nanofluid and copper oxide nanofluid increased the productivity by $41.18 \%$ and $32.32 \%$ relative to CSS (Sharshir et al. 2018). Asadpourian and Ameri (Asadpourian and Ameri 2021) analysed the CuO-GO nanocomposite in the solar still. The result showed that the $0.3,0.2$ and 0.1 mass $\%$ of nanocomposite increased the freshwater productivity by $44.7 \%, 75 \%$ and $91.7 \%$ 
respectively. Kandeal et al. (Kandeal et al. 2021) investigated the combination of inclusion of $\mathrm{Cu}_{2} \mathrm{O}$ nanoparticles and nano-enhanced PCM in the solar still. The result indicated that the combination of nanoparticles and nanophase change materials enhanced the productivity by $113 \%$ when compared to conventional solar still. The inclusion of naturally available nano/microparticles enhanced the evaporation rate. Baskaran and Saravanane (Baskaran and Saravanane 2021) experimentally studied the montmorillonite nanoparticles for desalination. The yield obtained was about 5.33 to $6.45 \mathrm{~kg} / \mathrm{m}^{2} /$ day during 14 testing days. Sampathkumar and Natarajan (Sampathkumar and Natarajan 2021a) experimentally investigated the inclusion of Borassus Flabellifer microsized particles in the absorber basin. It was found that productivity was increased by $35 \%$ on day 1 and $33 \%$ on day 2 .

\section{Productivity Enhancement of Solar Still by Inclusion of Thermal Storage System}

The inclusion of thermal storage systems such as Latent Heat and Sensible Heat Storage extended the operating time of solar still. The thermal storage systems absorb heat during diurnal and release it during nocturnal.

\section{Sensible Thermal Storage}

The sensible thermal storage materials absorb heat during the daytime and release it after the sunset without any change in its phase. Mohamed et al. (Mohamed et al. 2019) studied the performance of solar still by the inclusion of basalt stone as a sensible energy medium. The productivity was increased by $33.37 \%, 27.86 \%$ and $19.81 \%$ when the size of the stone was 2, 1.5 and $1 \mathrm{~cm}$, respectively. Gholizadeh and Farzi (Gholizadeh and Farzi 2020) analysed the still with sand as thermal storage, the results showed that the productivity was increased by 21.16 $\%$ relative to still without any thermal storage. Attia et al. (Attia et al. 2021) experimentally investigated the El Oued sandbags of 25 numbers, the results showed a $34.83 \%$ increase in productivity. Arunkumar et al. (Arunkumar et al. 2020) experimentally investigated the solar still with different sensible storage materials such as spherical clay balls, Polyvinyl Alcohol sponges, pebbles and absorber plates coated with copper oxide nanoparticles. From the experiments, it was found that the productivity of solar still with absorber plates coated with copper oxide nanoparticles, spherical clay balls, pebbles and Polyvinyl Alcohol sponges were 2.9, 2.6, 2.8 and $1.9 \mathrm{~L} / \mathrm{m}^{2}$.day respectively. Panchal et al. (Panchal et al. 2020) analysed the still with evacuated tubes and calcium stones. It was found that productivity was enhanced by $104.68 \%$ for the solar still contains evacuated tube with calcium stone whereas for solar still with the evacuated tube was $113.52 \%$. Dubey and Mishra (Dubey and Mishra 2020) analysed the double-slope still with ring magnets made up of ferrite and Galvanized Iron sheets. It was found that the increment of yield was $31.13 \%$ and the exergy efficiency was increased by 57.58 \%. Rajmanickam et al. (Rajamanickam et al. 2018) analysed the solar still with charcoal as energy storage 
material and the productivity was enhanced by $30.57 \%$ relative to CSS. Thakur et al. (Thakur et al. 2021) analysed the solar still integrated with a line focusing collector for the preheat of feed water and included activated carbon pellets for the energy storage. The results showed that productivity was increased by $85.2 \%$ in comparison with CSS. The preheating of feed water and inclusion of energy storage medium enhanced the productivity.

\section{Latent Thermal Storage}

The latent thermal storage materials absorb heat during sunshine hours and change their phase from solid to liquid. The absorbed heat energy was released during non-sunshine hours and returned to solid-state. The impregnation of micro/nanoparticles enhanced the thermal properties of novel PCM (Tariq et al. 2020)(Peng et al. 2021). Nian et al. (Nian et al. 2021) studied the solar still throughout a year with an absence of phase change energy materials, the results indicated that the incorporation of phase change materials in the solar still increased the productivity by $71.2 \%$ in comparison with conventional solar still without any energy storage medium. Shoeibi et al. (Shoeibi et al. 2021) studied the influence of the absorber coated with nano-particles and nanoenhanced PCM. The $\mathrm{CuO}$ and $\mathrm{Al}_{2} \mathrm{O}_{3}$ with the wt $\%$ of 0.1 and 0.3 respectively were mixed with phase change material and the black paint with copper oxide nanoparticles coated for absorber and the experiment was carried out. The results showed that productivity was increased by 55.8 and $49.5 \%$ for copper oxide and aluminium oxide nano-enhanced phase change material when compared with conventional still. Additionally, the nanocoated black paint increased the water production rate by $5.7 \%$. Russ et al. (Iniyan and Suganthi 2017) investigated the solar still with $0.3 \mathrm{wt} \%$ copper oxide phase change material and found that the productivity was enhanced by 35\%. Rufuss et al. (Dsilva Winfred Rufuss et al. 2018) studied the nano enhanced phase change materials with three nanoparticles such as titanium oxide, copper oxide and graphene oxide. The different nano enhance phase change materials were utilised for the solar still as thermal storage medium. The results revealed that the increased in productivity was $26 \%$ and $35 \%$ for nano enhanced $\mathrm{TiO}_{2}$ and $\mathrm{CuO}$ phase change materials respectively. It was also recommended that solar still with $\mathrm{CuO}$ nano enhanced PCM of 0.3 weight\% for better yield. Safaei et al. (Safaei et al. 2019) analysed the Graphene Oxide as the nanoparticles mixed with phase change material in the weight $\%$ of $0.2,0.4$ and 0.6 . The increase in productivity of $25 \%$ was obtained for $0.6 \mathrm{wt} \%$ nano enhanced phase change material.

\section{The novelty of the work}

From the summary of the literature survey, it was clear that the productivity of solar still can be increased by various approaches such as improvement of evaporation rate and enhancing productivity by the inclusion of 
thermal energy storage systems. The majority of the researchers examined the impact of nano/microparticles coated absorber basins. Some researchers investigated the inclusion of synthesised nanoparticles and naturally available microparticles in the absorber of solar still. Many researchers experimentally analysed the inclusion of thermal energy materials in the solar still to increase the operating time during non-sunshine hours. However, to the best of the author's knowledge, there was no specific work that focuses on the investigation of the combined effect of inclusion of Borassus Flabellifer Micro-Sized Particles in the absorber basin and micro Phase Change Material under the absorber basin for the enhancement of productivity.

The main objectives of this work are

1. To estimate the optimum weight of micro-sized palm powder in the absorber for maximum productivity.

2. To determine the optimised weight $\%$ of palm powder impregnated with phase change material paraffin wax for the better thermal energy storage system.

3. The experimentation of solar still with the combination of better weight $\%$ mPCM under the absorber basin and optimum weight of palm flower powder- micro-size in the absorber basin.

4. The evaluation of thermal, economic and environmental analysis of PCMPFP-SS and CSS.

The experimental investigation with different weights of micro-sized particles such as $10 \mathrm{~g}, 30 \mathrm{~g}, 45 \mathrm{~g}, 50 \mathrm{~g}, 55 \mathrm{~g}$, $70 \mathrm{~g}, 100 \mathrm{~g}, 120 \mathrm{~g}$, and $150 \mathrm{~g}$ in the absorber basin was performed. The experimental investigation has been carried out to determine the better wt $\%$ of micro-sized particles in the paraffin wax for enhanced thermal properties. The experimental analysis with the optimum weight of micro-sized particles in the absorber basin and better weight $\%$ of mPCM bed under the absorber basin was carried out during September 2021 at Science Block, National Institute of Technology Puducherry.

\section{Materials and Methods}

This section involves the fabrication of solar still, selection of material, preparation of mPCM, and methodology. The experimental work was performed along with error analysis was included.

\subsection{Materials and Setup of solar still}

Four similar solar stills were developed at the terrace of Science block, National Institute of Technology, Puducherry $\left(10.98{ }^{\circ} \mathrm{N}, 79.84^{\circ} \mathrm{E}\right)$ and the experimental setup is given in figure 1 . The solar stills were fabricated with plywood because of the better durability and stability of plywood. The interior area of solar stills was covered with a $2 \mathrm{~mm}$ thick aluminium sheet to reduce the interface of moisture with plywood. The aluminium sheet was coated with black colour to absorb more insolation. The thermocol of $3 \mathrm{~cm}$ thick was used to cover the outer sides of the solar still to prevent loss of heat to the atmosphere. The dimensions of each copper basin were $100 \times 60 \times$ 

was coated with selective coating Thurmalox because of its high absorptivity property. The saline water depth in the absorber basin was $2 \mathrm{~cm}$ and it was maintained throughout the experiment day. The top of solar still was enclosed with $4 \mathrm{~mm}$ thick transparent glass. The CPVC pipe was attached at the end of the solar still facing south to collect the freshwater from the bottom of the transparent glass cover. The measuring cylinder was positioned near the connecting pipe to collect the freshwater from the connected pipe.

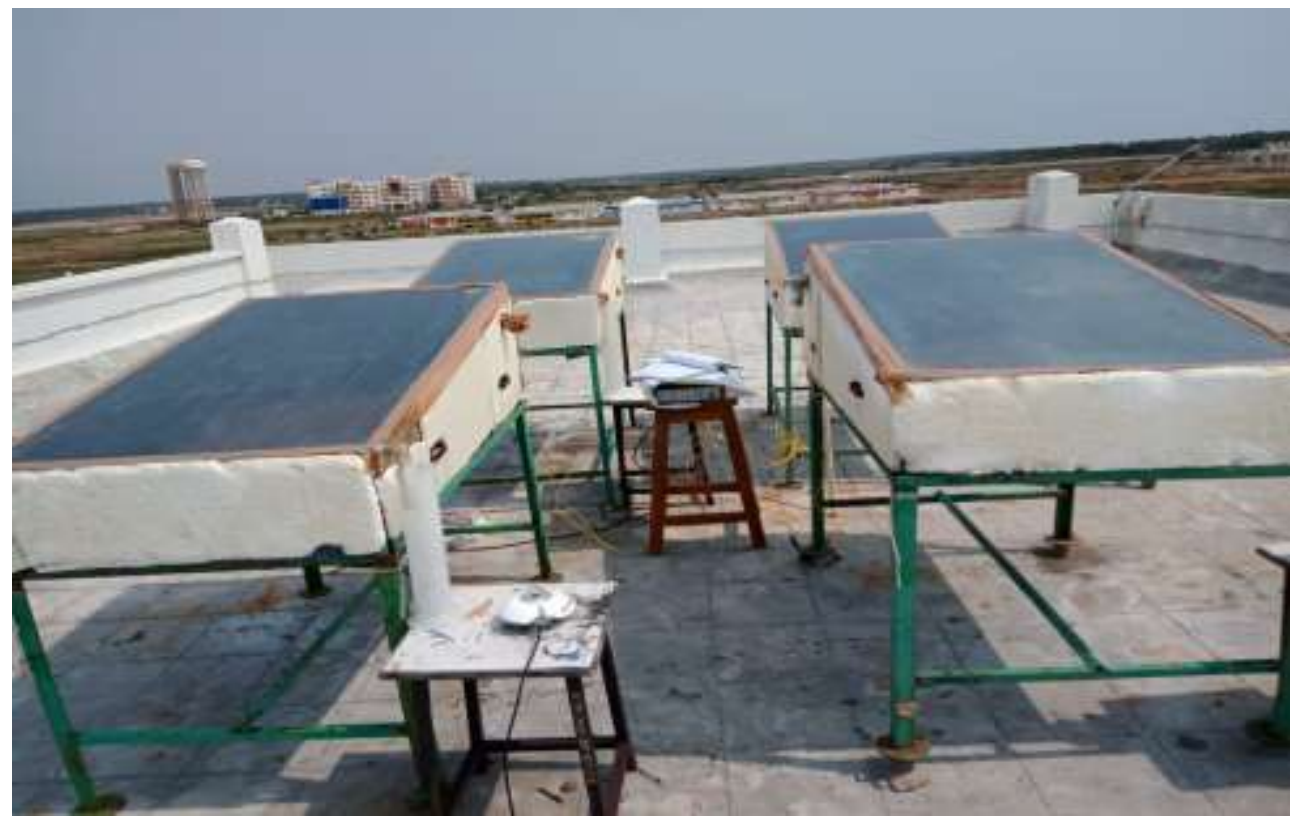

Fig 1. Experimental setup of solar stills

\subsection{Materials}

The naturally available and low-cost materials were chosen for the productivity enhancement in the solar still.

The material selected for the experimental work was male palm flower powder. The Borassus Flabellifer tree is native to India and Southeast Asia. The fruits from the tree have medicinal value, the other portions such as leaf, trunk, crown and roots were used for a variety of purposes. The flower from the male palm tree has good thermal properties. The palm tree was found abundant near the testing location, National Institute of Technology, Puducherry (NITPy). The palm tree flower was collected from the nearby testing range and blended into uniform micro-sized particles (Sampathkumar and Natarajan 2021a). The phase change material chosen for the preparation and experimentation of mPCM was paraffin wax. The paraffin wax was chosen because it has fast charging and high latent heat of absorption capacity. Furthermore, the paraffin wax is easily obtainable, safe to 

experimentation was procured from the local marketplace.

\section{$223 \quad 3.3$ Preparation of $\mathbf{m P C M}$}

224 The thermal conductivity of Phase Change material can be enhanced by the incorporation of micro-sized particles. The micro enhanced Phase Change Material reduced the charging time. The micro-sized particles fill the space between molecules of PCM and enhance the transfer of heat between the molecules. There is no substantial increment in thermal properties when more weight $\%$ of micro-sized particles are added to the paraffin wax. The optimum weight $\%$ of micro-sized particles enhances the thermal properties. In this regard, the samples were prepared with different weight $\%$ of micro-sized palm powder such as 5, 10, 15 and 20 wt $\%$. The paraffin wax was weighed using SHIMADZU CORPORATION BL - 220 H Type electronic balance machine. The paraffin wax was heated above its melting temperature using a hot plate of 12" diameter, 1500 Watts and 230 Volts. The micro-sized palm flower powder was mixed with liquid paraffin using a probe sonicator of model SM750PS. The samples with different weight\% of micro-sized palm flower powder such as 5, 10, 15 and 20 wt $\%$ were prepared. Each sample was sonicated with $1.5 \mathrm{kHz}$ for half an hour. The samples were allowed to cool until they attained stable equilibrium. The thermal conductivity of each sample was measured using TEMPOS thermal properties analyser TR-3 single needle of $2.4 \mathrm{~mm}$ diameter and $100 \mathrm{~mm}$ length. The process of preparation of sample with different weight $\%$ such as 5, 10, 15 and $20 \mathrm{wt} \%$ and the measurement of thermal conductivity of the sample is presented in figure 2 . The results of thermal conductivity with different weight $\%$ of palm flower powder is shown in figure 3.

240 It was observed that the thermal conductivity of mPCM with 5, 10, 15 and $20 \mathrm{wt} \%$. of micro-sized palm flower 241 powder were $0.25,0.30,0.31$ and $0.33 \mathrm{~W} / \mathrm{m}-\mathrm{K}$ respectively. From experiments, it was found that the thermal conductivity of mPCM with $25 \mathrm{wt} \%$ of micro-sized palm flower powder was $0.33 \mathrm{~W} / \mathrm{m}-\mathrm{K}$. The micro-sized palm flower powder sediment at $25 \mathrm{wt} \%$ of micro-sized palm flower powder in paraffin wax and there was no improvement in the thermal conductivity. The micro-sized particles occupied the space between molecules of paraffin wax and improved the heat transfer between the molecules. From the results, it was clear that the maximum thermal conductivity was attained at $20 \mathrm{wt} \%$ of palm flower powder in the paraffin wax which was $57.14 \%$ higher than novel paraffin wax. 


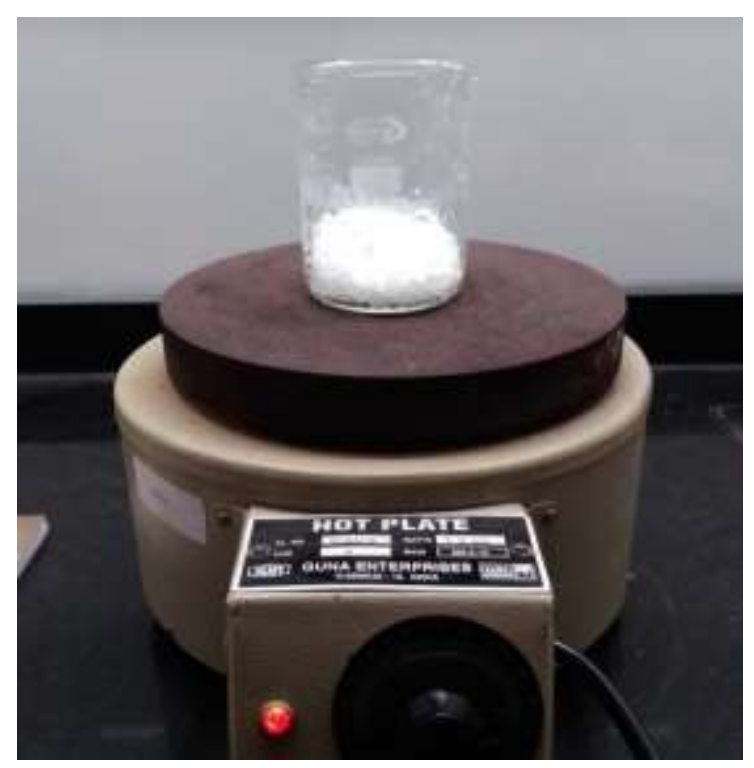

(a)

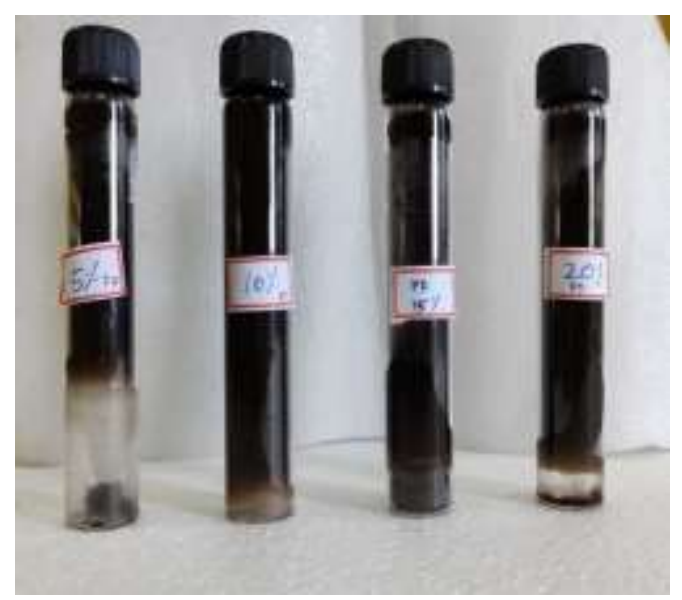

(c)

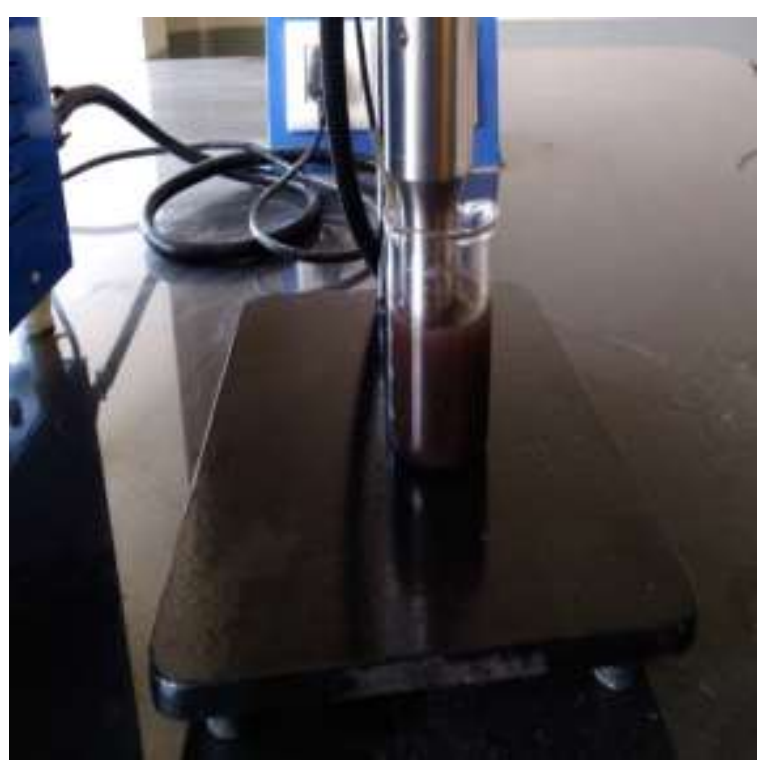

(b)

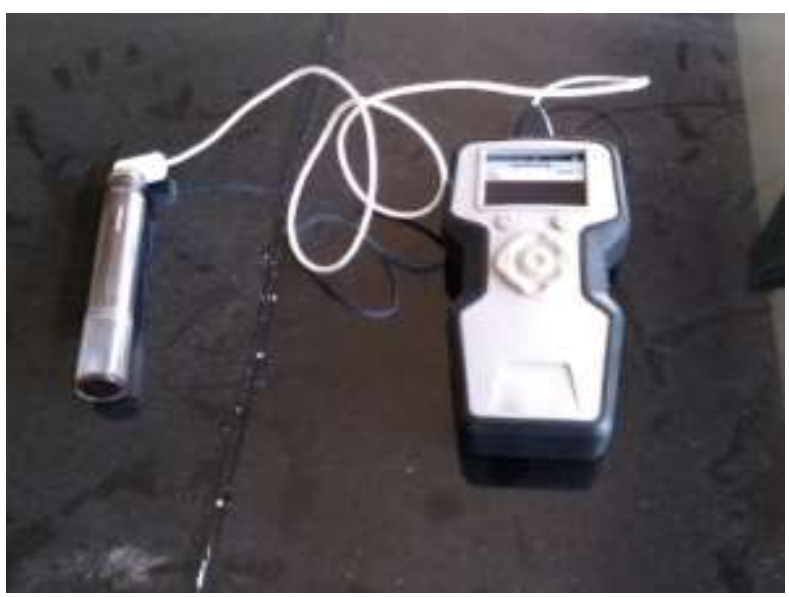

(d)

Fig. 2 (a) Hot Plate to melt PCM (b) Sonication process (c) Samples with different weight\% (d) TEMPOS thermal properties analyser 


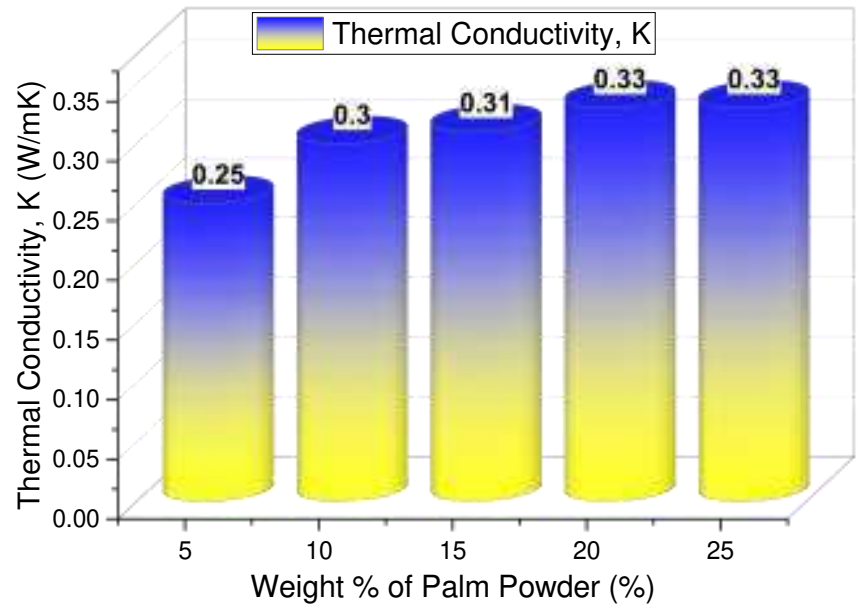

Fig. 3. Effect of thermal conductivity for different weight $\%$ of palm powder

\section{$252 \quad 3.4$ Experimental and Error Investigation}

253 The $\mathrm{k}$ type thermocouples were placed at the glass, water, absorber basin and PCM bed. The thermocouples were coupled to the Agilent 3492A Data acquisition system for recording the temperatures. The global radiation

255 was measured using Hukseflux Pyranometer. The temperatures at various locations on solar stills, global solar radiation and productivity were recorded for every half an hour from 08:00 A.M to 08:00 P.M (IST) during experiment days. Figure 4 depicts the methodology for the overall experimentation process. 


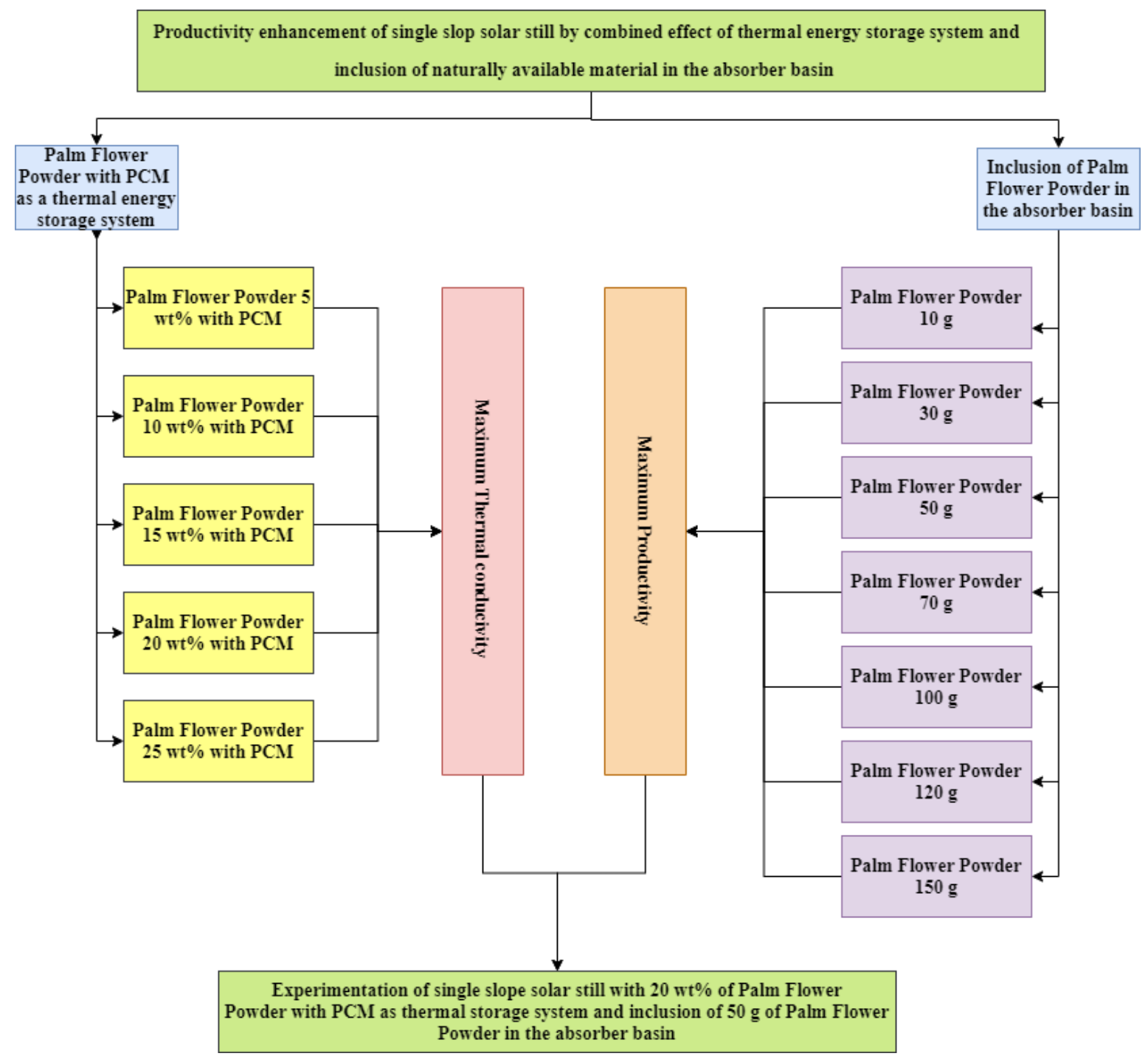

Fig 4. Methodology for the experimentation of PCMPFP-SS

260 The experiments were conducted to determine the optimal weight palm flower powder of micro-size in the 261 absorber for better productivity. The effect of various weights of palm flower powder of micro-size in the absorber basin was also investigated. In this regard, the different weights of palm flower powder of micro-size such as 10 $\mathrm{g}, 30 \mathrm{~g}, 50 \mathrm{~g}, 70 \mathrm{~g}, 100 \mathrm{~g}, 120 \mathrm{~g}$, and $150 \mathrm{~g}$ were experimentally investigated. The increase in productivity of different weights of palm flower powder of micro-size in the absorber basin is shown in figure 5 . 


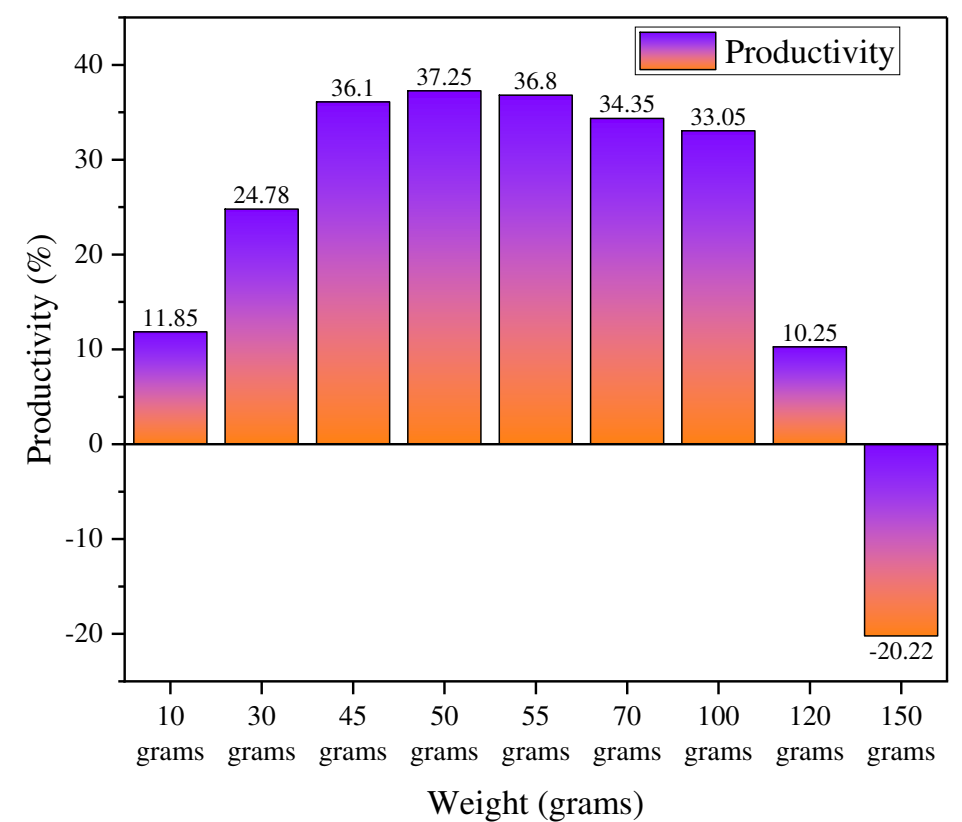

Fig. 5 Increase in productivity with different weight $\%$

266 From figure 5. it can be seen that the solar still with $50 \mathrm{~g}$ of palm flower powder of micro-size in the absorber 267 basin has the better productivity of $37.25 \%$, whereas, for $10 \mathrm{~g}, 30 \mathrm{~g}, 70 \mathrm{~g}, 100 \mathrm{~g}, 120 \mathrm{~g}$, and $150 \mathrm{~g}$ the increase in 268 productivity was $11.85 \%, 24.78 \%, \%, 34.35 \%, 33.05 \%, 10.25 \%$ and $-20.22 \%$ respectively. It was inferred 269 from the experimental results, that the more weight of palm flower powder of micro-size in the absorber basin 270 completely hindered the evaporation and the productivity was very much lower than conventional solar still. On 271 the other hand, the contribution of the lesser weight of palm flower powder of micro-size in the absorber basin for 272 the enhancement of productivity was very minimal. The optimum weight of palm flower powder of micro-size in 273 the absorber basin for better productivity was $50 \mathrm{~g}$. The experiments were carried out with $45 \mathrm{~g}$ and $55 \mathrm{~g}$ of palm 274 flower powder of micro-size in the absorber basin, the observed productivity was $36.1 \%$ and $36.8 \%$ respectively.

\subsubsection{Preparation of mPCM bed and Experimentation:}

The paraffin wax of $10 \mathrm{~kg}$ was filled in the solar still and allowed to change its phase from solid to liquid by absorbing solar radiation. The micro-sized palm flower powder of $20 \mathrm{wt} \%$ was mixed with liquid paraffin wax and allowed to solidify. It was ensured that the micro-sized particles were well mixed with liquid paraffin wax in the solar still. It was allowed to cool and attain its equilibrium state. The preparation of the MPCM bed is shown in figure 6. powder of $50 \mathrm{~g}$ in the absorber basin, $20 \mathrm{wt} \%$ of $\mathrm{mPCM}$ bed under the absorber basin and the Conventional Solar 
283 Still. On experiment days, the absorber basin was placed over the mPCM bed and saline water was filled with 2

$284 \mathrm{~cm}$ depth. The $50 \mathrm{~g}$ weight palm flower powder of micro-size was spread over the surface of the water in the 285 absorber. The top of solar still was enclosed with $4 \mathrm{~mm}$ thick transparent glass and ensured no heat leakage to 286 the ambient. The experimental setup of the combined effect of inclusion of micro-sized particles in the absorber 287 basin, mPCM and CSS is shown in figure 7.

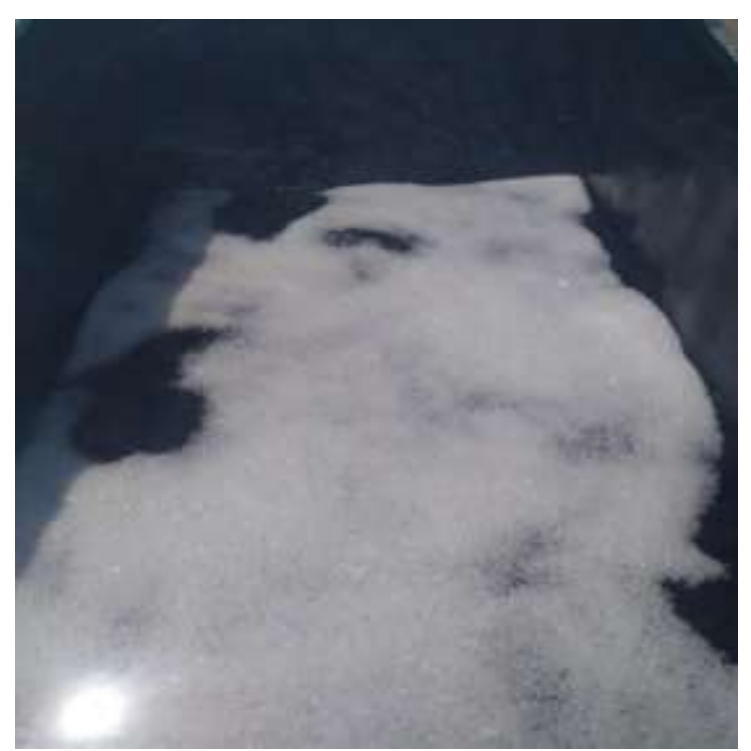

(a)

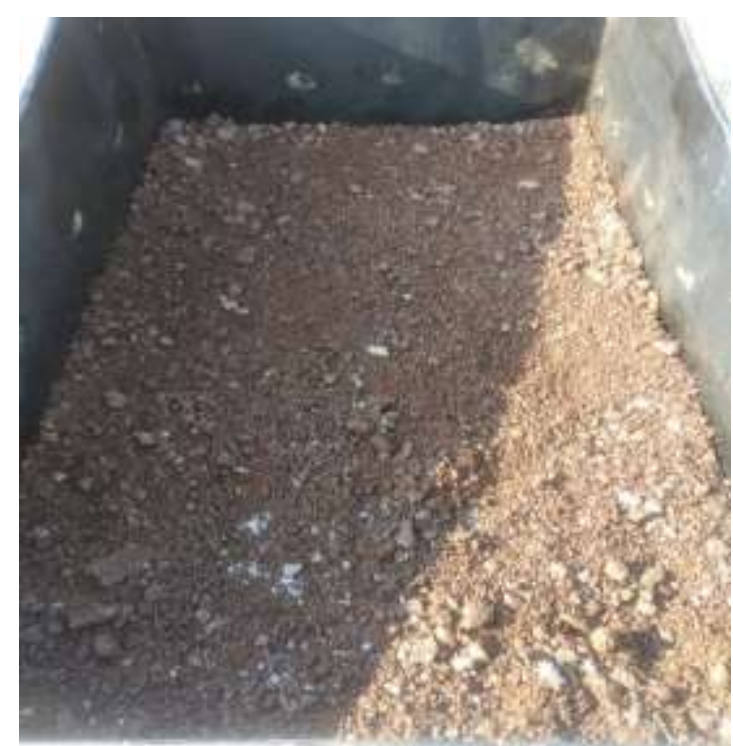

(b)

Fig 6 (a) paraffin wax in liquid state (b) MPCM bed 


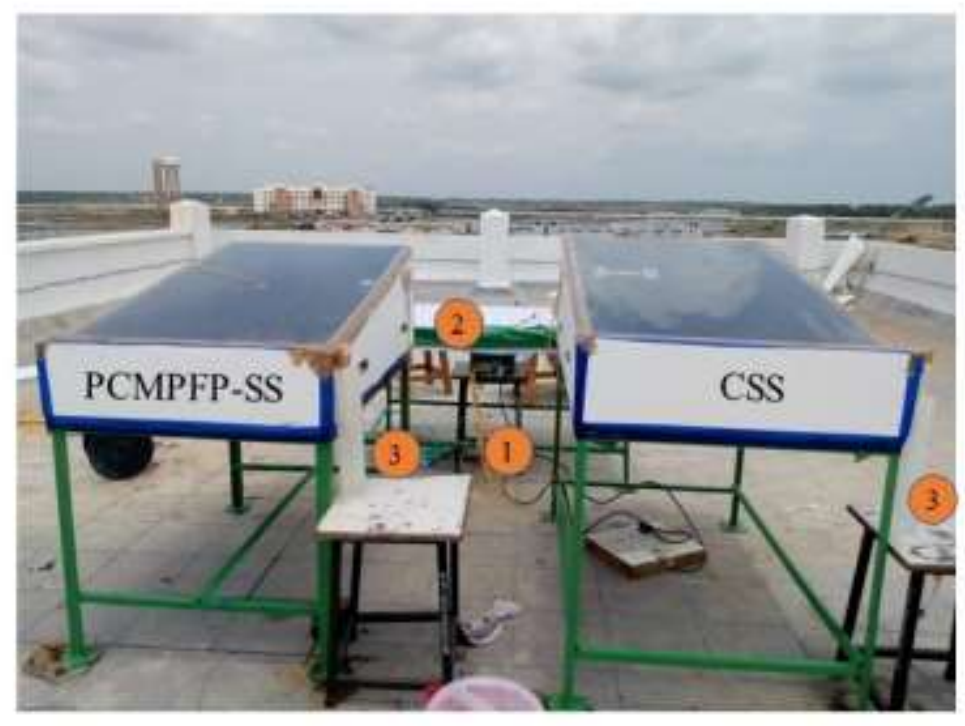

\section{(1) Thermocouples \\ (2) Data Logger \\ (3) Measuring Cylinder}

Fig.7 Experimental setup of PCMPFP-SS and CSS

291 The errors occur due to measuring instruments and during experimentation. The uncertainty of an experiment is due to random and systematic error. The uncertainty of each equipment associated with the experiment can be calculated using equation (1) (Suraparaju et al. 2021a)(Natarajan et al. 2021), the uncertainty in the productivity of each hour can be evaluated using equation 2 (Suraparaju and Natarajan 2021a)(Sampathkumar and Natarajan in table 1.

$$
\mathrm{U}=\frac{\mathrm{A}}{\sqrt{3}}
$$

Table 1. Uncertainty of instruments

\begin{tabular}{|l|l|l|l|l|}
\hline S. No & Instrument details & Accuracy (A) & Range & Uncertainty (U) \\
\hline 1 & $\begin{array}{l}\text { Thermal Properties } \\
\text { analyser }\end{array}$ & $\pm 10 \% \mathrm{~W} / \mathrm{mK}$ & $0.1-4.0 \mathrm{~W} / \mathrm{mK}$ & $0.058 \mathrm{~W} / \mathrm{mK}$ \\
\hline 2 & K type thermocouple & $\pm 0.1^{\circ} \mathrm{C}$ & -270 to $1,260{ }^{\circ} \mathrm{C}$ & $0.058^{\circ} \mathrm{C}$ \\
\hline 3 & Pyranometer & $\pm 10 \mathrm{~W} / \mathrm{m}^{2}$ & 0 to $1600 \mathrm{~W} / \mathrm{m}^{2}$ & $5.774 \mathrm{~W} / \mathrm{m}^{2}$ \\
\hline
\end{tabular}




\begin{tabular}{|l|l|l|l|l|}
\hline 4 & Cylinder & $5 \mathrm{ml}$ & 0 to $1000 \mathrm{ml}$ & $2.89 \mathrm{ml}$ \\
\hline
\end{tabular}

$\mathrm{u}_{d_{w}}=\left[\left(\frac{\mathrm{d}_{\mathrm{i}}-\mathrm{d}_{\mathrm{f}}}{\delta \mathrm{y}_{1}} u_{\mathrm{y}}\right)^{2}\right]^{\frac{1}{2}}$

$\mathrm{d}_{\mathrm{i}}-\mathrm{d}_{\mathrm{f}}$ is the difference between initial and final distillate at any time and $u_{\mathrm{y}}$ is the uncertainty in productivity.

\section{Thermal, Economic and Environmental Analysis}

- The solar still is in quasi-static condition

- There is no potential, kinetic impact on the solar still

- The inclination in transparent glass is constant

- The water depth is constant in the solar still

- There are no specific heat capacity for insulation and glass cover

- The thermophysical properties of water and glass cover are constant

In the thermal analysis the energy balance between solar still and global radiation is calculated by the energy balance equations and also the overall efficiency of the solar still can be calculated from the utilisation of global solar radiation with considering the heat transfer loss inside and outside solar still (Sharshir et al. 2017) (Dhivagar et al. 2021)(Elango et al. 2015). The equations of energy balance for water, absorber basin and glass for the solar still is presented from equations (3) to (7). The convection mode of heat transfer occurs between water and inner glass, the heat transfer coefficient in terms of Nusselt number is given in equation (8), and the Nusselt number is the function of two dimensionless numbers namely Grashof number and Prandtl number which are presented in equation (10) and (11), respectively. The total heat transfer coefficient inside the solar still and the total coefficient of heat transfer between glass cover and ambient is presented from equation (12) to (21) and equation (22) to (26) respectively. The hourly productivity and daily productivity of solar still can be calculated from equations (27) and (28). The instantaneous thermal efficiency and overall cumulative efficiency of the solar still is given in equations (29) and (30) respectively.

$$
\begin{aligned}
& \alpha_{w} \tau_{w} I A_{w}+h_{c}\left(T_{b}-T_{w}\right)=m_{w} C_{p w} \frac{d T_{w}}{d t}+h_{t, i}\left(T_{w}-T_{g}\right) \\
& h_{t, i}=h_{c, i}+h_{r, i}+h_{e, i}
\end{aligned}
$$


Energy balance equation for absorber basin

$$
\alpha_{b} \tau_{w} \tau_{g} I A_{b}=m_{b} C_{p b} \frac{d T_{b}}{d t}+h_{c}\left(T_{b}-T_{w}\right)+U_{b}\left(T_{b}-T_{a}\right)
$$

328

329

Energy balance equation for glass cover

$$
\begin{aligned}
& \alpha_{g} I A_{g}+h_{t}\left(T_{w}-T_{g}\right)=m_{g} C_{p g} \frac{d T_{g}}{d t}+h_{t, o}\left(T_{g}-T_{s}\right) \\
& h_{t, o}=h_{c, o}+h_{r, o}
\end{aligned}
$$

330

331 The convective heat transfer in terms of Nusselt number

$$
\begin{aligned}
& N u=\frac{h_{c, i} \times d}{K_{v}} \\
& N u=f(G r, P r)
\end{aligned}
$$

Where

$$
\begin{aligned}
& G r=\frac{g \beta d t d^{3} \rho^{2}}{\mu^{2}} \\
& \operatorname{Pr}=\frac{\mu C_{p v}}{K_{v}}
\end{aligned}
$$

334

335

The convection mode of heat transfer between saline water and the glass is

$$
\begin{aligned}
& Q_{c, i}=h_{c, i}\left(T_{w}-T_{g}\right) \\
& h_{c, i}=0.884 \times\left[\left(T_{w}-T_{g}\right)+\frac{\left(P_{w}-P_{g}\right)\left(T_{w}+273\right)}{268.9 \times 10^{3}-P_{w}}\right]^{\frac{1}{3}} \\
& P_{w}=e^{\left(25.317-\frac{5144}{T_{w}+273}\right)} \\
& P_{g}=e^{\left(25.317-\frac{5144}{T_{g}+273}\right)}
\end{aligned}
$$

336

337

The convection mode of heat transfer between saline water and the glass

$$
\begin{aligned}
& Q_{r, i}=h_{r, i}\left(T_{w}-T_{g}\right) \\
& h_{r, i}=\varepsilon_{e f f} \times \sigma\left[\left(T_{w}+273\right)^{2}+\left(T_{g}+273\right)^{2}+\left(T_{w}+T_{g}+546\right)\right] \\
& \varepsilon_{e f f}=\left(\frac{1}{\varepsilon_{g}}+\frac{1}{\varepsilon_{w}}-1\right)^{-1}
\end{aligned}
$$

The evaporation heat transfer between saline water and the glass

$$
\begin{aligned}
& Q_{e, i}=h_{e, i}\left(T_{w}-T_{g}\right) \\
& h_{e, i}=13.273 \times 10^{-3} \times h_{c, i} \times\left[\frac{\left(P_{w}-P_{g}\right)}{\left(T_{w}-T_{g}\right)}\right]
\end{aligned}
$$


The coefficient of overall heat transfer between water and glass is given by

$$
h_{t, i}=h_{c, i}+h_{r, i}+h_{e, i}
$$

342

343

The convection mode of heat transfer from glass to ambient

$$
\begin{aligned}
& Q_{c, o}=h_{c, o}\left(T_{g}-T_{a}\right) \\
& h_{c, o}=2.8+(3.0 \times v)
\end{aligned}
$$

344

345

The radiation heat transfer from glass cover to ambient

$$
Q_{r, o}=h_{r}\left(T_{g}-T_{a}\right)
$$

$$
h_{r, o}=\varepsilon_{g} \times \sigma\left[\frac{\left(T_{g}+273\right)^{4}-\left(T_{s}+273\right)^{4}}{\left(T_{g}-T_{a}\right)}\right]
$$

$$
T_{s}=T_{a}-6
$$

347 The hourly, daily productivity of solar still and instantaneous thermal efficiency is

$$
\begin{aligned}
& P_{h}=\frac{Q_{e, i}}{L_{h}} \times 3600 \\
& P_{d}=\sum_{i=1}^{24} P_{h} \\
& \eta_{\text {ins }}=\frac{Q_{e, i}}{I}
\end{aligned}
$$

The cumulative efficiency of the solar still is

$$
\eta_{\text {passive }}=\frac{\sum P_{h} \times L_{h}}{\sum I \times A \times 3600}
$$

Where $\sum P_{h}$ is the total yield on the day $(\mathrm{kg}), L_{h}$ is the latent heat of vaporisation of water $(\mathrm{J} / \mathrm{Kg}), \mathrm{A}$ is absorber basin $\left(\mathrm{m}^{2}\right)$ and $\sum I$ is the cumulative global radiation $\left(\mathrm{W} / \mathrm{m}^{2}\right)$ on the experiment days. The influence of modified solar still can be evaluated by comparing the increase in productivity with the conventional solar still. The altered solar still contains fibres and latent thermal storage materials. It is important to consider the economic view for modified solar still. The main objective of the economic analysis is to evaluate the Cost per Litre (CPL) and payback period of solar stills. The following assumptions are made for the analysis

1. The rate of interest, $\mathrm{r}$ is $15 \%$.

2. The salvage value is determined as 20 per cent of the fixed cost.

3. The lifespan of solar stills is 10 years 
4. The operation of solar still in a year is 280 days

The CPL and payback period for the PCMPFP-SS and CSS can be calculated using the following equations

362 (Suraparaju and Natarajan 2021a) (Suraparaju and Natarajan 2021b)

$$
\begin{aligned}
& \text { First Annual Cost }=\text { Capital Recovery Factor } \times \text { Initial Investment } \\
& \text { Capital Recovery Cost }=\frac{r(1+r)^{n}}{(1+r)^{n}-1} \\
& \text { Annual Sinkage Factor }=\text { Sinking Fund Factor } \times \text { Salvage Value } \\
& \text { Sinking Fund Factor }=\frac{r}{(1+r)^{n}-1} \\
& \text { Salvage Value }=0.2 \times \text { Initial Investment } \\
& \text { Annual Maintenance Cost }=0.15 \times \text { First Annual Cost } \\
& \text { Annual Cost }=\text { First Annual Cost }+ \text { Annual Maintenance Cost } \\
& \quad-\text { Annual Sinkage Factor } \\
& \text { Cost Per Litre }=\frac{\text { Annual Cost }}{\text { Yield for 280 days }} \\
& \text { Payback period }=\frac{\text { Net investment }}{\text { Total earned }}
\end{aligned}
$$

Total earned $=$ waterprice in market for a litre $\times$ Productivity per square metre

363

364

$$
\begin{aligned}
& \text { Annual } \mathrm{CO}_{2} \text { emission }(\mathrm{kg})=\frac{E_{\text {in }} \times 1.58}{n} \\
& \mathrm{CO}_{2} \text { emission }(\mathrm{kg})=E_{\text {in }} \times 1.58 \\
& E_{\text {out }}=\frac{M \times L_{h}}{3600} \\
& \mathrm{CO}_{2} \text { mitigation }(\mathrm{kg})=E_{\text {out }} \times n \times 1.58 \\
& N C E M \text { (in tons) }=\frac{\left[\left(E_{\text {out }} \times n\right)-E_{\text {in }}\right] \times 1.58}{1000} \\
& \text { Carbon Credit Gained }(\$)=N C E M \times \text { Cost of } \mathrm{CO}_{2} \text { traded per ton }
\end{aligned}
$$




\subsection{Ambient temperature, global radiation on experiment days}

373 The insolation and temperature of the atmosphere on the testing days are shown in figure 8 . The global radiation and ambient temperature readings were recorded at an interval of every half an hour from 8:00 A.M (IST) to 8:00 P.M (IST) on the experimentation days. The maximum solar radiation recorded on day 1 and day 2 were $974.95 \mathrm{~W} / \mathrm{m}^{2}$. The cumulative global radiation on day 1 was slightly higher than on day 2 . The cumulative global radiation on day 1 and day 2 were $14441.44 \mathrm{~W} / \mathrm{m}^{2}$ and $14150.30 \mathrm{~W} / \mathrm{m}^{2}$.

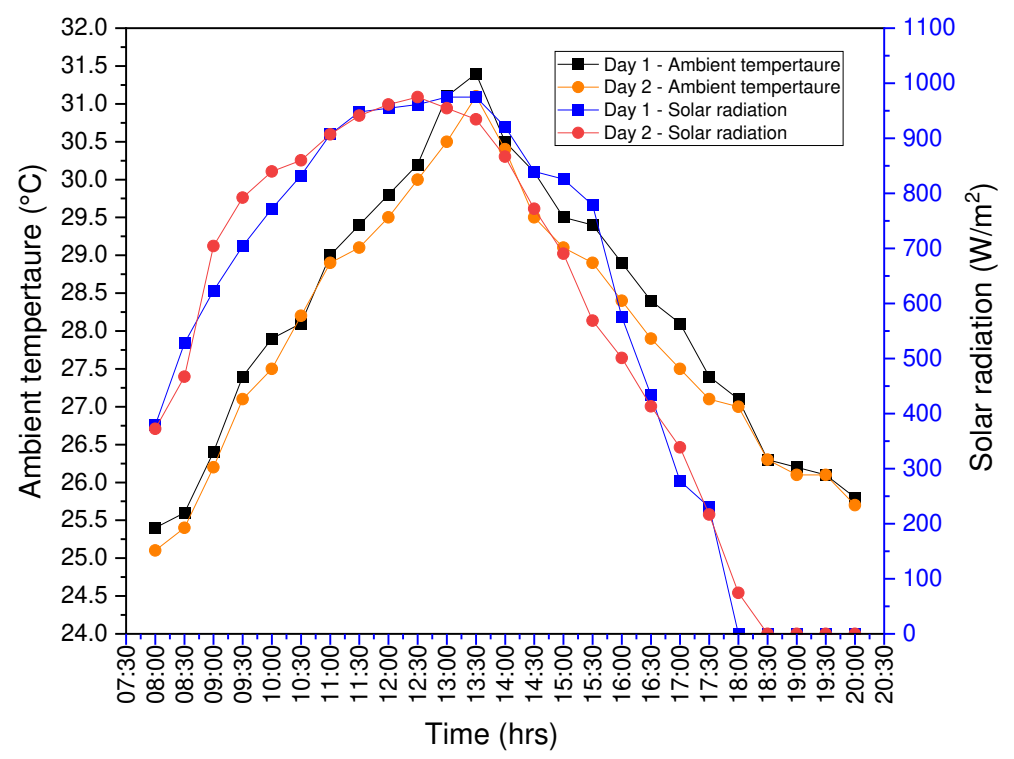

Figure 8. Variation of ambient temperature and solar radiation

The ambient temperature rises steadily reaches the maximum at noon and starts falling afternoon. The ambient temperature lies between $25.4{ }^{\circ} \mathrm{C}$ and $31.4{ }^{\circ} \mathrm{C}$ on day 1 whereas for day 2 it was between $25.1{ }^{\circ} \mathrm{C}$ and $31.1{ }^{\circ} \mathrm{C}$. The range of atmospheric temperature and global solar radiation was almost similar on both days. 5.2 Effect of micro-sized particles in the absorber basin \& micro PCM on the temperatures of solar still The temperatures at various locations such as glass, water, absorber for PCMPFP-SS and CSS on day 1 and the temperatures at the glass, water, absorber and MPCM bed for PCMPFP-SS are shown in figure 9. The maximum glass, water and absorber temperatures for CSS on day 1 were $54.4^{\circ} \mathrm{C}, 68.9{ }^{\circ} \mathrm{C}$ and $70.9^{\circ} \mathrm{C}$. The maximum glass, water and absorber and mPCM bed temperature attained in PCMPFP-SS on day 1 were $54.1{ }^{\circ} \mathrm{C}, 69.9{ }^{\circ} \mathrm{C}$ and 

temperature.

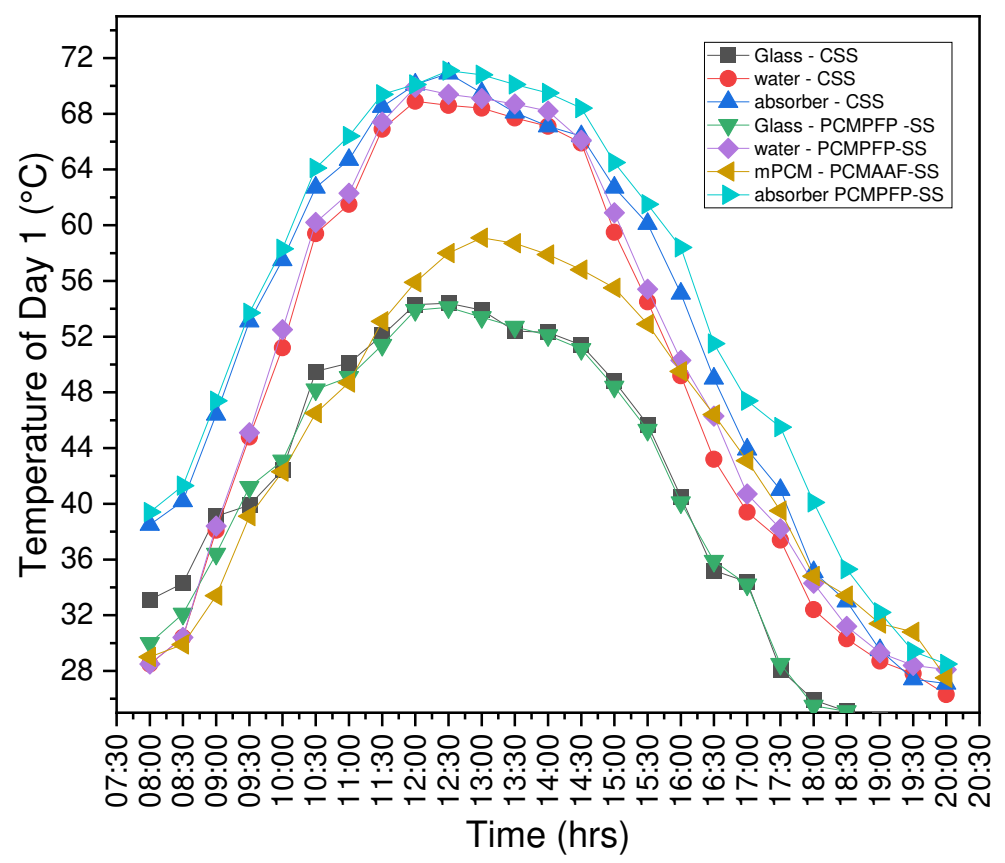

Figure 9. Variability in solar still temperatures - day 1

The temperature at the glass, water, absorber and MPCM for PCMPFP-SS and CSS on day 2 is shown in figure 10. The maximum glass, water and absorber temperatures for CSS on day 2 were $57.4{ }^{\circ} \mathrm{C}, 68.1{ }^{\circ} \mathrm{C}$ and $69.5^{\circ} \mathrm{C}$. The maximum glass, water and absorber and MPCM bed temperature attained in PCMPFP-SS on day 2 were $57.5^{\circ} \mathrm{C}, 68.9^{\circ} \mathrm{C}$ and $70.4{ }^{\circ} \mathrm{C}$ and $58.5^{\circ} \mathrm{C}$. The water and absorber temperature was less during the morning when compared to glass temperature. The peak temperature at the glass, water, absorber and mPCM was attained from 1:00 P.M (IST) to 1:30 P.M (IST) on both days. 


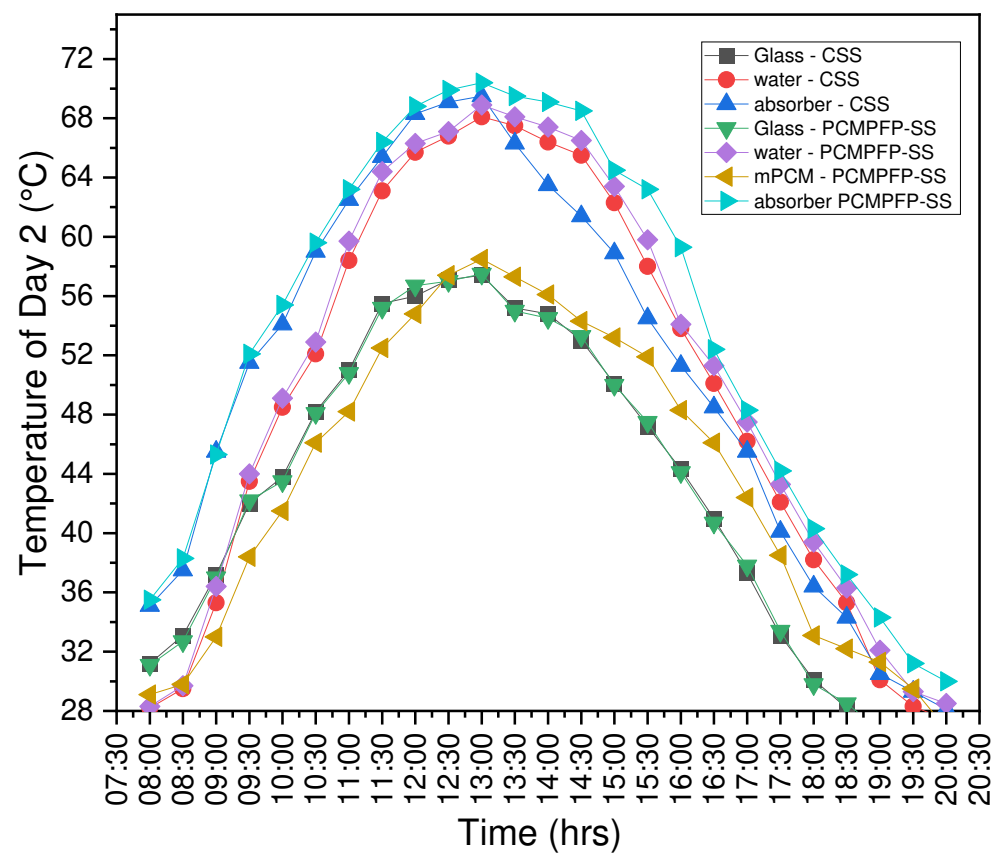

Figure 10. Variability in solar still temperatures - day 2

The insolation on the experiment days increased the water and absorber temperature. The water temperature of PCMPFP-SS was higher than CSS due to the inclusion of micro-sized particles in the absorber basin. The microsized particles in the absorber basin increased the surface area and water temperature by the absorption of heat from global radiation. The higher water temperature in PCMPFP-SS leads to more evaporation rate. It was observed from the results that the temperature of glass in PCMPFP-SS was slightly lesser than CSS. This is due to the transfer of heat to mPCM under the absorber. It was noticed that the temperature of the absorber in PCMPFP-SS was higher than CSS was extended during non-shine hours. The heat absorbed by mPCM was released to the absorber and returned to the solid by releasing the stored energy. The temperature difference between water and glass for evaporation was extended even after the non-shine hours. The productivity in conventional solar still was ended from 5:00 to 5:30 P.M (IST) on both days, whereas the productivity in PCMPFP-SS was extended up to 8:00 P.M (IST).

\subsection{Productivity}

The instantaneous productivity for CSS and PCMPFP-SS on day 12 are presented in figure 11 . The cumulative productivity for CSS and PCMPFP-SS on day 1 and day 2 are presented in figure 12. 


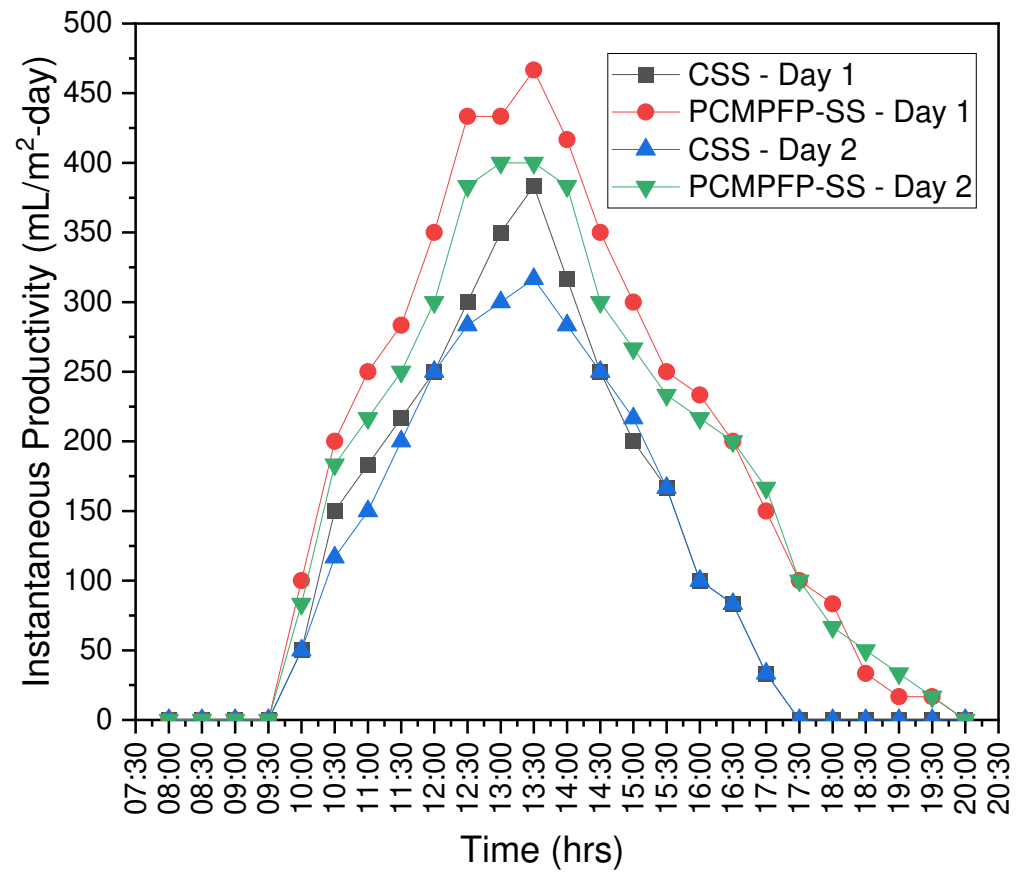

Figure 11. Solar stills instantaneous productivity on day 1 and day 2

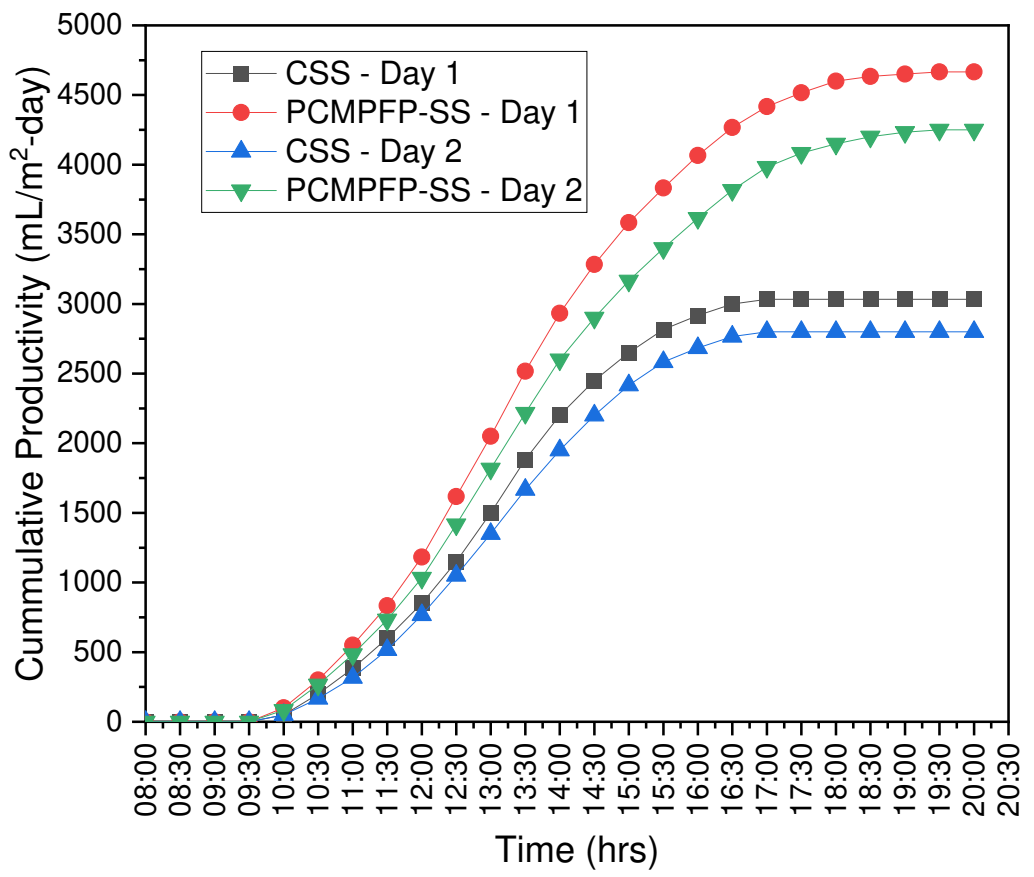

Figure 12. Solar stills cumulative productivity on day 1 and day 2 
415 From figure 11 it was clear that the maximum hourly productivity for PCMPFP-SS was $470 \mathrm{ml} / \mathrm{m}^{2}$-day on day

4161 and $400 \mathrm{ml} / \mathrm{m}^{2}$-day on day 2. The maximum hourly productivity occurred at 01:30 P.M (IST) on day 1 and day

417 2. The maximum hourly productivity for CSS was $380 \mathrm{ml} / \mathrm{m}^{2}$-day on day 1 and $320 \mathrm{ml} / \mathrm{m}^{2}$-day on day 2 . The 418 yield of CSS and PCMPFP-SS upto 5:00 P.M (IST) were $3030 \mathrm{ml} / \mathrm{m}^{2}$-day and $4420 \mathrm{ml} / \mathrm{m}^{2}$-day respectively. The 419 yield of CSS and PCMPFP-SS upto 5:00 P.M (IST) on day 2 were $2800 \mathrm{ml} / \mathrm{m}^{2}$-day and $3980 \mathrm{ml} / \mathrm{m}^{2}$-day 420 respectively. The increase in productivity of PCMPFP-SS on day 1 and day 2 was due to the inclusion of palm 421 flower powder in the absorber. The hourly productivity of PCMPFP-SS decreased gradually after 05:30 P.M 422 (IST) and ended at 08:00 P.M (IST) whereas for CSS it was ended at 05:00 P.M (IST). The continuation of 423 hourly productivity in PCMPFP-SS on day 1 and day 2 was due to the inclusion of the mPCM bed. From figure 424 12. it is clear that the aggregated productivity of PCMPFP-SS was higher than CSS. The yield for CSS attained 425 steady after 5:00 P.M (IST) to 5:30 P.M (IST) on both days whereas for PCMPFP-SS the yield continued till 07:30 P.M (IST). The productivity of both PCMPFP-SS and CSS was higher on day 1 compared to day 2 because of more insolation on day 1. The total yield of CSS and PCMPFP-SS on days 1 and 2 are represented in figure 13.

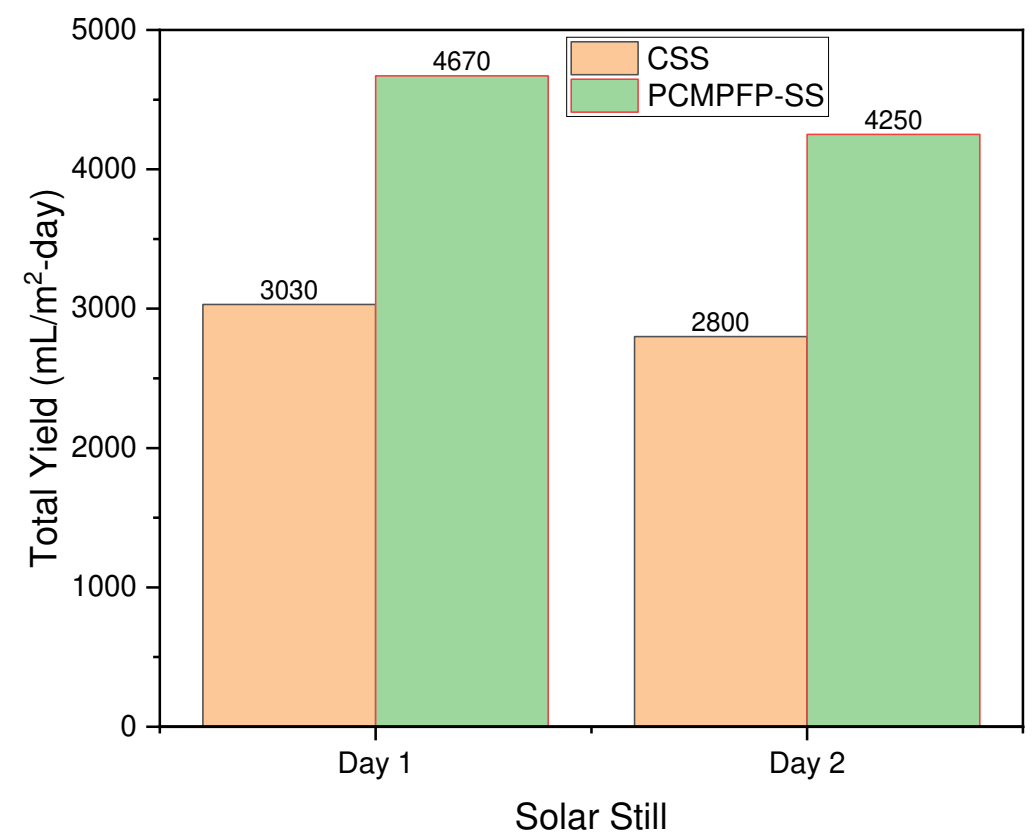

Figure 13. Total yield comparison of solar still on day 1 and day 2

From the figure, it is clear that the yield of PCMPFP-SS was higher than CSS. The total yield for PCMPFP-SS 
day 1 and $2800 \mathrm{ml} / \mathrm{m}^{2}$-day on day 2 . The increase in productivity of solar still with micro-sized particles in the absorber basin \& micro Phase Change Material at bottom of the basin was $54.12 \%$ on day 1 and $51.78 \%$ on day 2 compared to conventional solar still. The increase in productivity was due to the combined effect of the inclusion of palm flower powder-micro size in the absorber and mPCM bed under the absorber.

\subsection{Effect of micro-sized particles in the absorber basin \& micro PCM on the productivity of solar still}

The productivity was enhanced significantly due to the inclusion of palm flower powder micro-sized in the absorber basin. The palm flower powder of micro-sized in the absorber basin increased the more surface area for evaporation. The global radiation increased the water temperature of PCMPFP-SS than CSS. It was observed that the inclusion of palm flower- micro-sized powder increased the evaporation rate. The amount of palm flower powder in the absorber basin played a significant role in the increase of productivity. The more amount of palm powder in the absorber completely obstructed the evaporation. It was observed that due to the presence of more amount of palm flower powder in the absorber basin the insolation takes more time to raise the water temperature hence the evaporation was reduced drastically. On the other hand, there was no significant improvement in productivity with the minimal amount of palm powder in the absorber. Additionally, the inclusion of mPCM bed under the absorber basin extended the hourly productivity upto 8:00 P.M (IST). The heat was transferred to mPCM during sunshine hours and the state of phase change material was changed from solid to liquid. The stored heat was released to the absorber and returned to its original state. It was observed that the productivity of PCMPFP-SS after 5:00 P.M (IST) were $1640 \mathrm{ml} / \mathrm{m}^{2}$-day on day 1 and $1450 \mathrm{ml} / \mathrm{m}^{2}$-day on day 2 . The inclusion of a thermal energy storage system increased the operating time of solar still resulting in extended hourly productivity relative to CSS. The overall yield results indicated that the inclusion of optimum weight of palm flower powder in the absorber enhanced the rate of evaporation and the inclusion of MPCM bed increased the operating time of solar still. The combined effect of the inclusion of palm flower powder micro-sized and mPCM enhanced the productivity of PCMAAF-SS relative to CSS.

\subsection{Thermal Economic and Environmental Analysis}

The efficiency of both the PCMPFP-SS and CSS were calculated for both the days of experimentation. The results showed that the efficiency for PCMPFP-SS was $42.59 \%$ on day 1 and $39.57 \%$ on day 2 . The efficiency for CSS was $27.68 \%$ and $26.07 \%$ for day 1 , day 2 respectively. The increase in efficiency for PCMPFP-SS was $53.8 \%$ on day 1 and $51.7 \%$ on day 2 . The increase in efficiency was due to the inclusion of micro-sized particles and thermal storage in the solar still. The thermal storage materials increased the operating hours of solar still, hence the productivity was increased. The Cost per Litre and payback period for PCMPFP-SS and CSS were 
462 calculated using equations from (4) to (13). The value for each parameter is presented in table 2. The cost per

463 litre and payback period for PCMPFP-SS and CSS is presented in figure 14. The individual components of

464 embodied energies are presented in table 3. The results from the evaluation of environmental analysis are given 465 in table 4.

Table 2. Economic Analysis of CSS and PCMPFP-SS

\begin{tabular}{|l|l|l|}
\hline Parameters & CSS & PCMPFP-SS \\
\hline Initial Investment & $₹ 9000$ & ₹ 11000 \\
\hline Capital Recovery Cost & 0.198 & 0.198 \\
\hline First Annual Cost & 1782 & 2178 \\
\hline Sinking Fund Factor & 0.049 & 0.049 \\
\hline Salvage Value & 1800 & 2200 \\
\hline Annual Sinkage Factor & 88.2 & 107.8 \\
\hline Annual Maintenance Cost & 270 & 330 \\
\hline Annual Cost & 1981 & 2422 \\
\hline Yield for 280 days & $816 \mathrm{~L} / \mathrm{m}^{2}$ & $1248 \mathrm{~L} / \mathrm{m}^{2}$ \\
\hline Cost Per Litre & $₹ 2.4=0.032 \mathrm{USD}$ & ₹ $1.9=0.025$ USD \\
\hline Payback period & $5.1 \mathrm{months}$ & $4.1 \mathrm{months}$ \\
\hline
\end{tabular}




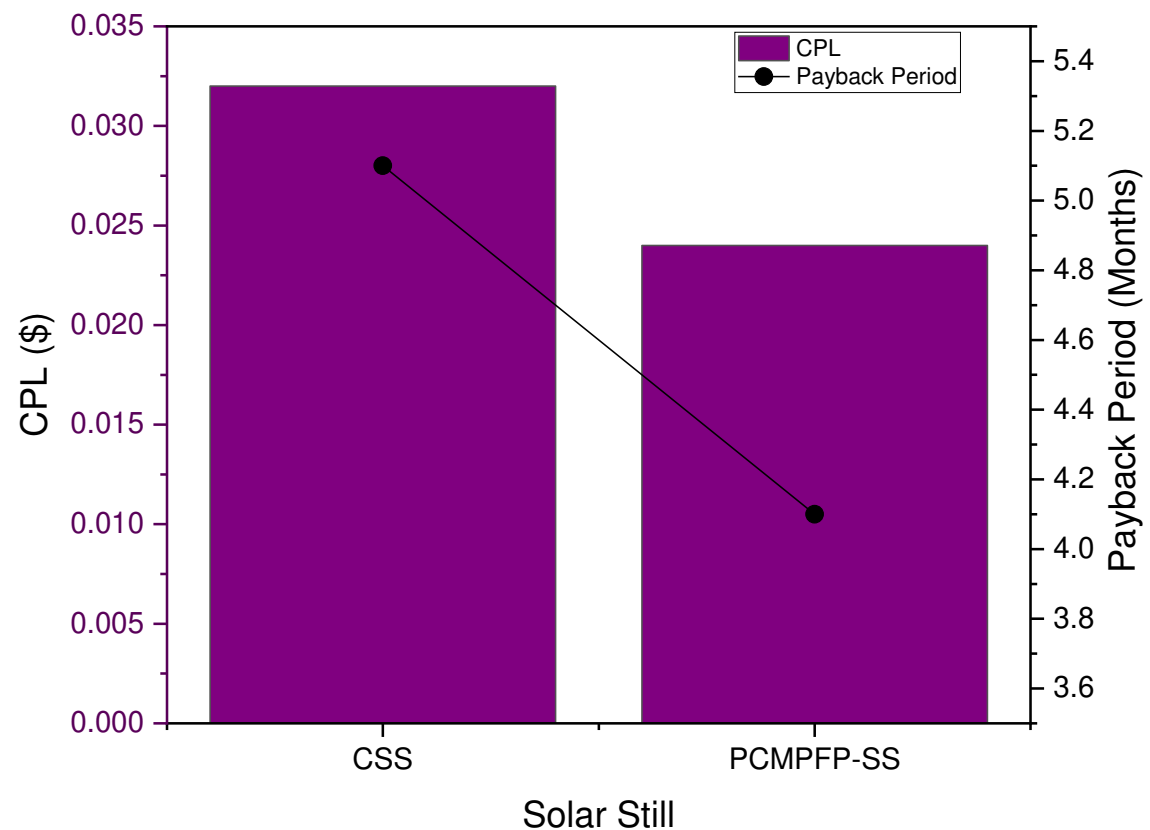

Figure 14. Comparison of CPL and Payback Period of both solar still

Table 3. Embodied energies of CSS and PCMPFP-SS

\begin{tabular}{|c|c|c|c|c|c|c|c|c|c|}
\hline Components & Setup & $\begin{array}{c}\text { Setup Inner } \\
\text { layer }\end{array}$ & Basin & Cover & Insulation & $\begin{array}{c}\text { Basin } \\
\text { Coating }\end{array}$ & $\begin{array}{l}\text { Storage } \\
\text { Medium }\end{array}$ & $\begin{array}{c}\text { Total } \\
\text { embodied } \\
\text { energy } \\
\left(\mathbf{E}_{\text {ia }}\right) \\
\end{array}$ & \\
\hline Materials & Plywood & Aluminium & Copper & Glass & Thermocol & Black paint & PCM & MJ & $\mathrm{kWh}$ \\
\hline Weight (kg) & 20 & 4 & 10 & 6 & 0.3 & 0.2 & 10 & - & - \\
\hline $\begin{array}{c}\text { Specific } \\
\text { Embodied } \\
\text { Energy }(\mathrm{MJ} / \mathrm{kg})\end{array}$ & 18 & 330 & 90 & 15 & 117 & 90 & 26.2 & - & - \\
\hline $\begin{array}{l}\text { Embodied } \\
\text { energy }(\mathrm{MJ}) \text { for } \\
\text { CSS }\end{array}$ & 360 & 1320 & 900 & 90 & 35.1 & 18 & - & 2723.1 & 756.4 \\
\hline $\begin{array}{l}\text { Embodied } \\
\text { energy (MJ) for } \\
\text { PCMPFP-SS }\end{array}$ & 360 & 1320 & 900 & 90 & 35.1 & 18 & 262 & 2985.1 & 829.1 \\
\hline
\end{tabular}




\begin{tabular}{|l|c|c|}
\hline \multicolumn{1}{|c|}{ Parameters } & CSS & PCMPFP-SS \\
\hline Embodied Energy $\left.\mathrm{E}_{\text {in, }}, \mathrm{kWh}\right)$ & 756.4 & 829.1 \\
\hline Annual Energy Output, $\mathrm{E}_{\text {out }}(\mathrm{kWh})$ & 679.7 & 1040 \\
\hline Lifetime $\mathrm{CO}_{2}$ emission for (kg) & 1195.11 & 1309.97 \\
\hline Lifetime $\mathrm{CO}_{2}$ mitigation (ton) & 10.7 & 16.4 \\
\hline Lifetime net $\mathrm{CO}_{2}$ mitigation (ton) & 9.54 & 15.12 \\
\hline Gain of Carbon Credit (\$) & 133.56 & 211.68 \\
\hline
\end{tabular}

475 The Cost per Litre for PCMPFP-SS and CSS were \$ 0.025 and \$ 0.032 respectively. The payback period for

476 PCMPFP-SS was reduced from 5.1 months to 4.1 months. The embodied energies of each component associated 477 with PCMAAF-SS and CSS are presented in Table 3. The results of different parameters from the environmental 478 investigation are shown in table 4 . The solar stills lifespan was taken as 10 years. The total embodied energy associated with CSS and PCMPFP-SS were $756.4 \mathrm{kWh}$ and $829.1 \mathrm{kWh}$ respectively. The net $\mathrm{CO}_{2}$ mitigation for the lifetime (in ton) of PCMAAF-SS was higher than CSS. From the economic point of view, the carbon credited for 1 ton is equal to \$14, from the analysis it was shown that the gain of carbon credit from PCMPFP-SS and CSS were \$211.68 and \$ 133.5 respectively.

\section{Conclusion:}

484 The purpose of this work was to experimentally investigate the productivity enhancement of single slope solar still by the inclusion of naturally available Borassus Flabellifer micro-sized particles in the absorber basin and micro Phase Change Material (mPCM) under the absorber basin. The experiments were carried out with different weights of palm powder-micro sized in the absorber basin of solar still such as $10 \mathrm{~g}, 30 \mathrm{~g}, 45 \mathrm{~g}, 50 \mathrm{~g}, 55 \mathrm{~g}, 70 \mathrm{~g}$, $100 \mathrm{~g}, 120 \mathrm{~g}$, and $150 \mathrm{~g}$ for the estimation of optimum micro-sized particles in the absorber basin. The mPCM samples were prepared with different weight\% of Borassus Flabellifer Micro-Sized Particles such as 5, 10, 15 and $20 \mathrm{wt} \%$, impregnated in the paraffin wax for better thermal conductivity. Two solar stills were developed and the experimentations were carried out during September 2021. The two solar stills were solar still with $50 \mathrm{~g}$ palm flower powder in the absorber basin, 20wt\% mPCM as thermal storage materials (PCMPFP-SS) and CSS. The overall yield of PCMPFP-SS was compared with CSS. The thermal, environmental and economic analysis was evaluated for PCMPFP-SS and CSS. 
i. The inclusion of optimum weight of palm flower powder in the absorber basin enhanced the evaporation resulting in more yield than CSS. The optimum weight of palm flower powder-micro sized in the absorber basin was $50 \mathrm{~g}$.

ii. The increase in productivity with different weight of palm flower powder such as $10 \mathrm{~g}, 30 \mathrm{~g}, 45 \mathrm{~g}, 50 \mathrm{~g}$, $55 \mathrm{~g}, 70 \mathrm{~g}, 100 \mathrm{~g}, 120 \mathrm{~g}$, and $150 \mathrm{~g}$ were $11.85 \%, 24.78 \%, 36.10 \%, 37.25 \%, 36.80 \%, 34.35 \%, 33.05$ $\%, 10.25 \%$ and $-20.22 \%$ respectively.

iii. The mPCM with maximum thermal conductivity was obtained at $20 \mathrm{wt} \%$ of palm flower powder

iv. The yield for PCMPFP-SS was $4670 \mathrm{ml} / \mathrm{m}^{2}$-day, $4250 \mathrm{ml} / \mathrm{m}^{2}$-day on day 1 and day 2 respectively,

vii. From the environmental analysis, it was found that the total embodied energy associated for PCMPFPSS and CSS was $829.1 \mathrm{kWh}$ and $756.4 \mathrm{kWh}$ respectively, whereas the carbon credit gained for PCMPFP-SS was 211.6 \$ and for CSS it was \$ 133.56.

517 The authors wish to acknowledge the KPR Institute of Engineering and Technology, Coimbatore for permitting to use TEMPOS thermal properties analyser.

\section{Declarations}

520 Ethics approval and consent to participate: Not applicable

521 Consent for Publication: Not applicable

522 Availability of data and materials: The datasets used and/or analysed during the current study are available from 523 the corresponding author on reasonable request.

524 Competing interests: The authors declare that they have no competing interests. 
Arivazhagan Sampathkumar: Conceptualization, Formal analysis, Investigation, Data Curation, Writing -

Original Draft.

Sendhil Kumar Natarajan: Conceptualization, Validation, Resources, Writing- Review \& Editing,

530

531

532

533

534

535

536

537

538

539

540

541

542

543

544

545

546

547

548

549

550

551

552

553

554

555

556

557

558

559

560

561

562

563

564

565

566

567

568

569

570

Supervision, Project administration.

\section{Reference:}

Ahmed FE, Khalil A, Hilal N (2021) Emerging desalination technologies: Current status, challenges and future trends. Desalination 517:. https://doi.org/10.1016/j.desal.2021.115183

Arunkumar T, Wang J, Dsilva Winfred Rufuss D, et al (2020) Sensible desalting: Investigation of sensible thermal storage materials in solar stills. Journal of Energy Storage 32:101824. https://doi.org/10.1016/j.est.2020.101824

Asadpourian E, Ameri A (2021) Enhancement of solar still productivity using CuO-GO nanocomposite: An experimental approach. Journal of the Taiwan Institute of Chemical Engineers 124:41-52. https://doi.org/10.1016/j.jtice.2021.05.008

Attia MEH, Kabeel AE, Abdelgaied M, Driss Z (2021) Productivity enhancement of traditional solar still by using sandbags of El Oued, Algeria. Heat Transfer 50:768-783. https://doi.org/10.1002/htj.21903

Baskaran V, Saravanane R (2021) Dispersed solar still for effective desalination using montmorillonite nanoparticles for sturdy clean water yield. Annals of Laparoscopic and Endoscopic Surgery 70:674-683. https://doi.org/10.2166/aqua.2021.139

Baskaran V, Saravanane R, Govindaradjane S (2021) Experimental Study on Domestic Solar Still Desalination with Cotton Gauze: An Approach to Field Model. Journal of The Institution of Engineers (India): Series A 102:713-718. https://doi.org/10.1007/s40030-021-00547-8

Bhargva M, Yadav A (2021) Factors affecting the performance of a solar still and productivity enhancement methods: A review. Environmental Science and Pollution Research. https://doi.org/10.1007/s11356-021$15983-\mathrm{z}$

Dhivagar R, Mohanraj M, Raj P, Gopidesi RK (2021) Thermodynamic analysis of single slope solar still using graphite plates and block magnets at seasonal climatic conditions. Water Science \& Technology 1-17. https://doi.org/10.2166/wst.2021.156

Dsilva Winfred Rufuss D, Suganthi L, Iniyan S, Davies PA (2018) Effects of nanoparticle-enhanced phase change material (NPCM) on solar still productivity. Journal of Cleaner Production 192:9-29. https://doi.org/10.1016/j.jclepro.2018.04.201

Dubey A, Kumar S, Arora A (2021) Enviro-energy-exergo-economic analysis of ETC augmented double slope solar still with ' $N$ ' parallel tubes under forced mode: Environmental and economic feasibility. Journal of Cleaner Production 279:123859. https://doi.org/10.1016/j.jclepro.2020.123859

Dubey M, Mishra DR (2020) Thermo-exergo-economic analysis of double slope solar still augmented with ferrite ring magnets and gi sheet. Desalination and Water Treatment 198:19-30. https://doi.org/10.5004/dwt.2020.25947

Elango C, Gunasekaran N, Sampathkumar K (2015) Thermal models of solar still - A comprehensive review. Renewable and Sustainable Energy Reviews 47:856-911

Fale SM, Choudhary R, Dogra S (2021) A study on the effect of absorbing medium on solar desalination system. Materials Today: Proceedings. https://doi.org/10.1016/j.matpr.2021.08.138

Gholizadeh M, Farzi A (2020) Performance Improvement of the single slope Solar Still Using Sand. Journal of Solar Energy Research 5:560-567

Hassan H, Ahmed MS, Fathy M (2019) Experimental work on the effect of saline water medium on the performance of solar still with tracked parabolic trough collector (TPTC). Renewable Energy 135:136- 
Ho ZY, Bahar R, Koo CH (2021) A comprehensive review on small-scale passive solar stills for desalination. Environmental Technology Reviews 10:188-212. https://doi.org/10.1080/21622515.2021.1921056

Iniyan S, Suganthi L (2017) Nanoparticles Enhanced Phase Change Material ( NPCM ) as Heat Nanoparticles Enhanced Phase Change Material ( NPCM ) as Heat Storage in Solar Still Application for Productivity Enhancement. In: Energy Procedia. pp 45-49

Jani HK, Modi K V. (2018) A review on numerous means of enhancing heat transfer rate in solar-thermal based desalination devices. Renewable and Sustainable Energy Reviews 93:302-317. https://doi.org/10.1016/j.rser.2018.05.023

Kabeel AE, El-Maghlany WM, Abdelgaied M, Abdel-Aziz MM (2020) Performance enhancement of pyramidshaped solar stills using hollow circular fins and phase change materials. Journal of Energy Storage 31:101610. https://doi.org/10.1016/j.est.2020.101610

Kabeel AE, Manokar AM, Sathyamurthy R, et al (2019) A review on different design modifications employed in inclined solar still for enhancing the productivity. Journal of Solar Energy Engineering, Transactions of the ASME 141:1-10. https://doi.org/10.1115/1.4041547

Kandeal AW, El-Shafai NM, Abdo MR, et al (2021) Improved thermo-economic performance of solar desalination via copper chips, nanofluid, and nano-based phase change material. Solar Energy 224:13131325. https://doi.org/10.1016/j.solener.2021.06.085

Mathioulakis E, Belessiotis V, Delyannis E (2007) Desalination by using alternative energy: Review and stateof-the-art. Desalination 203:346-365. https://doi.org/10.1016/j.desal.2006.03.531

Modi K, Jani H (2021) Experimental and theoretical assessment of dual-slope single-basin solar still with the circular cross-sectional hollow-fins. Cleaner Engineering and Technology 4:100231. https://doi.org/10.1016/j.clet.2021.100231

Modi K V., Modi JG (2020) Influence of wick pile of jute cloth on distillate yield of double-basin single-slope solar still: Theoretical and experimental study. Solar Energy 205:512-530. https://doi.org/10.1016/j.solener.2020.05.086

Mohamed AF, Hegazi AA, Sultan GI, El-Said EMS (2019) Enhancement of a solar still performance by inclusion the basalt stones as a porous sensible absorber: Experimental study and thermo-economic analysis. Solar Energy Materials and Solar Cells 200:109958. https://doi.org/10.1016/j.solmat.2019.109958

Mostafavi A, Parhizi M, Jain A (2020) Semi-analytical thermal modeling of transverse and longitudinal fins in a cylindrical phase change energy storage system. International Journal of Thermal Sciences 153:106352. https://doi.org/10.1016/j.ijthermalsci.2020.106352

Moungar H, Ahmed A, Youcef S, Aabdelkrim H (2017) Immersed fins influence on the double slope solar still production in south Algeria climatic condition. International Journal of Heat and Technology 35:10651071. https://doi.org/10.18280/ijht.350444

Natarajan SK, Suraparaju SK, Elavarasan RM, et al (2021) An experimental study on eco-friendly and costeffective natural materials for productivity enhancement of single slope solar still. Environmental Science and Pollution Research 1-20. https://doi.org/10.1007/s11356-021-15764-8

Nian Y Le, Huo YK, Cheng WL (2021) Study on annual performance of the solar still using shape-stabilized phase change materials with economic analysis. Solar Energy Materials and Solar Cells 230:111263. https://doi.org/10.1016/j.solmat.2021.111263

Panchal H, Hishan SS, Rahim R, Sadasivuni KK (2020) Solar still with evacuated tubes and calcium stones to enhance the yield: An experimental investigation. Process Safety and Environmental Protection 142:150155. https://doi.org/10.1016/j.psep.2020.06.023

Patel M, Patel C, Panchal H (2019) Past, present and future of the active solar distillation system: a comprehensive review. International Journal of Ambient Energy 0:1-23. https://doi.org/10.1080/01430750.2019.1684996 
Peng G, Sharshir SW, Wang Y, et al (2021) Potential and challenges of improving solar still by micro/nanoparticles and porous materials - A review. Journal of Cleaner Production 311:127432. https://doi.org/10.1016/j.jclepro.2021.127432

Qiblawey HM, Banat F (2008) Solar thermal desalination technologies. Desalination 220:633-644. https://doi.org/10.1016/j.desal.2007.01.059

Rajamanickam MR, Velmurugan P, Ragupathy A, Sivaraman E (2018) Use of thermal energy storage materials for enhancement in distillate output of double slope solar still. Materials Today: Proceedings 34:416-419. https://doi.org/10.1016/j.matpr.2020.02.203

Safaei MR, Goshayeshi HR, Chaer I (2019) Solar Still E ffi ciency Enhancement by Using Graphene Oxide / Para ffi n Nano-PCM. Energies 1-13

Sampathkumar A, Natarajan SK (2021a) Experimental Investigation on Productivity Enhancement in Single Slope Solar Still Using Borassus Flabellifer Micro-Sized Particles. Materials Letters 299:130097. https://doi.org/10.1016/j.matlet.2021.130097

Sampathkumar A, Natarajan SK (2021b) Experimental Investigation of Single Slope Solar Still with Eucheuma ( Agar-Agar ) Fibre for Augmentation of Freshwater Yield: Thermo-Economic Analysis. Environmental Progress \& Sustainable Energy 1-8. https://doi.org/10.1002/ep.13750

Saravanan A, Murugan M (2020) Performance evaluation of square pyramid solar still with various vertical wick materials - An experimental approach. Thermal Science and Engineering Progress 19:100581. https://doi.org/10.1016/j.tsep.2020.100581

Sharon H, Reddy KS (2015) A review of solar energy driven desalination technologies. Renewable and Sustainable Energy Reviews 41:1080-1118. https://doi.org/10.1016/j.rser.2014.09.002

Sharshir SW, Elkadeem MR, Meng A (2020a) Performance enhancement of pyramid solar distiller using nanofluid integrated with v-corrugated absorber and wick: An experimental study. Applied Thermal Engineering 168:114848. https://doi.org/10.1016/j.applthermaleng.2019.114848

Sharshir SW, Eltawil MA, Algazzar AM, et al (2020b) Performance enhancement of stepped double slope solar still by using nanoparticles and linen wicks: Energy, exergy and economic analysis. Applied Thermal Engineering 174:115278. https://doi.org/10.1016/j.applthermaleng.2020.115278

Sharshir SW, Kabeel AE, Elsheikh AH, Peng G (2017) Thermal performance and exergy analysis of solar stills - A review. Renewable and Sustainable Energy Reviews 73:521-544

Sharshir SW, Peng G, Elsheikh AH, et al (2018) Energy and exergy analysis of solar stills with micro/nano particles: A comparative study. Energy Conversion and Management 177:363-375. https://doi.org/10.1016/j.enconman.2018.09.074

Sharshir SW, Peng G, Elsheikh AH, et al (2020c) Influence of basin metals and novel wick-metal chips pad on the thermal performance of solar desalination process. Journal of Cleaner Production 248:119224. https://doi.org/10.1016/j.jclepro.2019.119224

Shinde M, Navthar R, Shinde PS (2020) Performance analysis of single slope solar still with improved design. International Journal of Ambient Energy 0:1-13. https://doi.org/10.1080/01430750.2020.1722227

Shoeibi S, Kargarsharifabad H, Rahbar N (2021) Effects of nano-enhanced phase change material and nanocoated on the performance of solar stills. Journal of Energy Storage 42:103061. https://doi.org/10.1016/j.est.2021.103061

Shubhajyothi H, Ganesh R, Manikandan V, Bhavani T (2020) Performance evaluation of a tilted wick type solar still by using the concept of solar fraction. Materials Today: Proceedings 37:1112-1132. https://doi.org/10.1016/j.matpr.2020.06.345

Singh SK, Kaushik SC, Tyagi VV, Tyagi SK (2021) Comparative Performance and parametric study of solar still: A review. Sustainable Energy Technologies and Assessments 47:101541. https://doi.org/10.1016/j.seta.2021.101541

Suraparaju SK, Dhanusuraman R, Natarajan SK (2021a) Performance evaluation of single slope solar still with novel pond fibres. Process Safety and Environmental Protection 154:142-154. 
Suraparaju SK, Natarajan SK (2021a) Productivity enhancement of single-slope solar still with novel bottom finned absorber basin inserted in phase change material (PCM): techno-economic and enviro-economic analysis. Environmental Science and Pollution Research 28:45985-46006. https://doi.org/10.1007/s11356-021-13495-4

Suraparaju SK, Natarajan SK (2021b) Experimental investigation of single-basin solar still using solid staggered fins inserted in paraffin wax PCM bed for enhancing productivity. Environmental Science and Pollution Research 28:20330-20343. https://doi.org/10.1007/s11356-020-11980-w

Suraparaju SK, Sampathkumar A, Natarajan SK (2021b) Experimental and economic analysis of energy storage-based single-slope solar still with hollow-finned absorber basin. Heat Transfer. https://doi.org/10.1002/htj.22136

Tariq SL, Ali HM, Akram MA, et al (2020) Nanoparticles enhanced phase change materials (NePCMs)-A recent review. Applied Thermal Engineering 176:115305. https://doi.org/10.1016/j.applthermaleng.2020.115305

Thakur AK, Sathyamurthy R, Velraj R, et al (2021) Sea-water desalination using a desalting unit integrated with a parabolic trough collector and activated carbon pellets as energy storage medium. Desalination 516:115217. https://doi.org/10.1016/j.desal.2021.115217

Thirugnanasambandam M, Iniyan S, Goic R (2010) A review of solar thermal technologies. Renewable and Sustainable Energy Reviews 14:312-322. https://doi.org/10.1016/j.rser.2009.07.014 